\title{
Financial liberalisation: from segmented to integrated economies
}

\author{
Fatma Taskin ${ }^{\mathrm{a}, 1}$, Gulnur Muradoglu ${ }^{\mathrm{b}, *}$ \\ a Department of Economics, Bilkent University, Ankara 06533, Turkey \\ ${ }^{\mathrm{b}}$ Cass Business School, Barbican Centre, Faculty of Finance, City University, \\ Frobisher Crescent, London EC2Y 8BH, UK
}

\begin{abstract}
Capital market liberalisation transforms segmented stock markets into integrated ones. Further impact should be expected on the dynamics of the rest of the domestic economy. This study presents evidence to that effect. A significant change after liberalisation is the emergence of world returns as an influential factor on other economic fundamentals. The information content of world returns influences emerging market returns prior to capital market liberalisation and this relation continues after capital market liberalisation. What is new after liberalisation is the influence of world returns on the dynamics of the domestic economy as a whole and its relation to stock returns.
\end{abstract}

(c) 2003 Elsevier Inc. All rights reserved.

JEL classification: G10; G15; C23

Keywords: Financial liberalisation; Emerging markets; Economic fundamentals

\section{Introduction}

Financial liberalisation refers to a series of regulatory changes that allow foreign investors to buy domestic assets and domestic citizens to invest in foreign assets, which makes the domestic securities market an integral part of the world capital markets. The process is mainly defined

\footnotetext{
* Corresponding author. Tel.: +44-20-7477-0124; fax: +44-20-7477-8853.

E-mail addresses: taskin@bilkent.edu.tr (F. Taskin), G.Muradoglu@ city.ac.uk (G. Muradoglu).

${ }^{1}$ The majority of this work has been conducted while the author was a visiting fellow in The Manchester School of Accounting and Finance, The University of Manchester, Manchester, UK.
} 
as a series of regulatory changes that open up the capital markets to foreign investors with the introduction of depository receipts, country funds or equity capital flows to the emerging economy.

The success of capital market liberalisation and the extent of integration to the world markets have mainly been investigated on the basis of two outcomes of liberalisation and their consequences. These are the changes in the rates of return ${ }^{1}$ and the increase in the growth of the emerging economy. ${ }^{2}$ There might be a wide variation in the breadth and methodology of the empirical work but the effect of liberalisation on the rates of return in emerging markets and on the growth rates of developing economies are widely accepted phenomena. However, the empirical literature that analyses the effect of liberalisation ignored one important aspect of the integration process.

Liberalisation is in fact aimed at integrating the local economy as a whole into the world economy and therefore capital market liberalisations are introduced as tools to that effect. If the capital market liberalisations are successful in changing the composition of these securities markets as they are integrated with the world, the process ought to have a significant impact on the links between the capital markets and the real and financial sectors of emerging economies. One naturally wonders how the interactions among the several aspects of the economy and capital markets change as a result of the increased interaction with the world.

The objective of this paper is to examine the interactions between domestic capital markets, domestic economic fundamentals and world capital markets before and after financial liberalisation. We expand existing knowledge by studying the changes that capital market liberalisations trigger in domestic economies and their relation to stock markets. We expect the remainder of the economy to be better integrated with the world and to carry on the impact of globalisation to local capital markets. We anticipate emerging capital markets to influence and be influenced by the equilibrium adjustments in the other sectors of the economy. Therefore, we investigate the direction and strength of these links before and after capital market liberalisations. The changes in the information content and predictive power of the economic fundamentals are treated as evidence of the transformations that occur in the dynamics of the economy.

We show that after, liberalisation, the importance of world stock returns within the domestic economy increases and there are increased interactions between economic fundamentals and domestic stock returns. Previous literature emphasises the world integration aspect of the capital markets. This study shows that the information content of world returns influenced emerging market returns prior to capital market liberalisation. This relationship continued after liberalisation. The significant change after capital market liberalisation is the emergence of world returns as an influential factor on other economic fundamentals, such as real economic activity and foreign exchange rates. Following capital market liberalisation, emerging economies are better exposed to global influences and consequently, dynamic relations between the components of the emerging economy and stock markets adapt.

This paper is organised as follows. The next section presents literature review. Section 3 describes the data set and explains the econometric methodology. Section 4 discusses the empirical results and Section 5 concludes. 


\section{Review of literature}

\subsection{Liberalisation reforms and capital markets}

The pace of liberalisation differs from country to country; however, in most countries liberalisation efforts were adopted progressively. In terms of the sequencing of reforms in trade, foreign exchange and capital market, each country presents a special case. Often, macro-economic stabilisation and privatisation programs accompany the liberalisation of the domestic economy. The establishment of domestic capital markets is advocated for the early stages of the Mc. Kinnon (1973) and Show (1973) type liberalisation process in order to increase the production financed by borrowing funds from domestic sources. The establishment of domestic stock markets in conjunction with a realistic interest rate policy is expected to serve as a vehicle to mobilise savings to private sector investments (Hartman \& Khambata, 1993). The availability of funds for equity issues will enable firms to decrease their over-reliance on debt finance, which is the major source of funding for firms in most pre-liberalisation emerging economies. As a result, operational efficiency, competitiveness and solvency are expected to increase (Murinde, 1996).

Capital market liberalisation has been the most important stage in transforming closed economies. During the 1970s, the main source of international funds was commercial bank lending to the domestic governments of the developing countries of the period. Since then, there has been a vast change in the significance of the capital markets. Foreign direct investments and portfolio flows became the dominant source of capital inflows to emerging economies during the 1990s. The past decade witnessed the increase in foreign direct investments from $0.5 \%$ of the GDP during the 1980s to $1 \%$ during the 1990s. Portfolio flows during the same period increased from practically 0 to $40 \%$ of the GDP (Bacchetta \& Wincoop, 2000). Therefore, today, capital market liberalisation and the opening of the emerging markets economies to foreign investment is undeniably the most important stage of the liberalisation of emerging economies.

\subsection{Capital market liberalisation and economic activity}

In economic theory, capital markets constitute one of the mechanisms through which savings can be channeled towards investment. In addition to other financial markets such as money, bond or foreign exchange markets they operate alongside the real sector, i.e., goods and labor markets. In a well-functioning economy, changes in the equilibrium conditions in any of these markets will be transmitted to others. When there is free flow of information and no restrictions on markets, market prices are expected to carry information to different markets and adjust to clear excess demand. An adjustment, which starts in one market is passed on to other sectors through the price mechanism. However, if there are regulations that either restrict the information flow or block the transmission channels, then markets will fail to respond to the changes in the rest of the economy.

Prior to liberalisations in emerging economies, capital markets are not open to international investors and regulations do not allow the residents of the country to invest internationally. Thus, capital markets are segregated from the rest of the world (Bekaert \& Harvey, 1995; Stulz, 1999). Most often, these emerging capital markets are operating in repressed financial environments, where there are severe liquidity constraints. Large-scale transactions can be made 
continuously and instantaneously, without moving the price drastically, only if the market is liquid (Bekaert \& Harvey, 1995). Lack of liquidity, which is essential for effective dissemination of information, can discourage the foreign investors. Furthermore, interest rates do not reflect the cost of borrowing in these credit markets where the government play a major role in the allocation of credit. Savings per GDP ratios are low compared to both the investment opportunities that exist in these economies and the ratios in developed countries. Thus, capital markets in emerging economies are segregated not only from the world but also from the rest of the domestic economy.

Capital markets, with their low volume of trade and few major dominant securities, are not a crucial element of economic activity either as transmission channels of information across different markets or as mechanisms that allocate optimal ownership structures in the economy. Thus, the flow of information both from the capital market to the rest of the economy and from the rest of the markets to the capital market is expected to be rather weak and limited in this period.

Following liberalisation, major changes take place in emerging capital markets. As foreign investors bid-up local prices in order to obtain superior diversification benefits, the correlation between emerging markets and the world increases (Bekaert \& Harvey, 2000b). The increase in the level of equity indexes indicates a reduction in aggregate cost of equity, holding expected future cash flows constant (Henry, 2000a). The cost of capital decline is thought to be due to risk sharing and the liquidity effects of increased inflow of capital. The increase in the supply of loanable funds, even with the same savings, is expected to lead to a decrease in the risk free rate. Furthermore, increased liquidity and risk sharing with the international investors decrease liquidity and the equity premium components of risk.

In addition to the changes that occur in the stock market, there are also significant adjustments in the overall economy. Stock market liberalisation, together with other reforms is associated with a rise in private investments (Henry, 2000b). Through the faster rate of physical accumulation and the increase in the economic efficiency, capital market liberalisation also promotes faster output growth. Countries that go through financial liberalisation also go through a number of legal and regulatory changes to boost financial development and accelerate long-run growth. Empirical evidence (Levine, Loayza, \& Beck, 2000) suggests that laws, regulations and enforcement mechanisms directly influence the functioning of financial intermediaries. Financial intermediaries that improve information dissemination and reduce transaction costs induce efficient allocation of resources and increase growth rates.

\subsection{World integration of emerging economies through capital market liberalisation}

We argue that, capital market liberalisation will alter the structural dynamics of an economy aside from the changes in the fundamentals of markets, such as security prices, cost of capital, investments and output growth rates. Our main focus is the increased information flow from the world to the emerging economy as a whole. This paper is distinct from previous research on capital market liberalisation mainly in that we perceive the integration process as the establishment of new linkages across different markets. We represent economic and financial activity as closely associated with backward and forward linkages. We argue that capital market liberalisation facilitates transactions and information flows amongst the different sectors of the economy 
and the world. For the changes in the dynamics of the emerging markets, we concentrate on the linkages among (i) world and domestic capital markets, (ii) world capital markets and domestic fundamentals, (iii) domestic capital markets and domestic fundamentals.

We treat integration as a process rather than a once and for all change, and we look for evidence of integration in the dynamics of the economy using Granger type causal orderings. We apply econometric methodology to panel data. Panel estimators capture the information in both the time series and cross-section and expose general patterns in emerging markets. Our emphasis is not on individual country cases ${ }^{3}$ but on the isolation of common elements from country specific factors. The construction of our data set and the choice of pre- and post-liberalisation periods are consistent with our understanding of capital liberalisation as a process. The choice of reform dates and sample partitioning is crucial for our results and we were thorough in discriminating the pre-liberalisation period from the post-liberalisation period in the panel.

\section{Data and methodology}

\subsection{Data}

The data set used in this study consists of monthly time series observations for 1976:011997:06. The start of the sample is dictated by the availability of stock market and economic fundamentals information for a wide set of countries. The sample ends before the beginning of the financial crisis in South Asia, which might have diverse effects on the countries in our sample. To examine the relations of stock returns with domestic economic fundamentals and world stock markets, we construct a six variable equation set. A total of 15 emerging markets that underwent an initial stock market liberalisation process during the late 1980s or early 1990s are considered. ${ }^{4}$ The domestic cost of borrowing is represented by interest rates. The industrial production index reflects the changes in the domestic real economic activity, and domestic money supply is an indicator of the economic policies and the level of liquidity. Foreign exchange rates are included to capture the effects of international competitiveness. The conditions in the world stock markets are summarized by S\&P500. ${ }^{5}$ To make international comparisons possible all variables are converted to real values using the consumer price indices of each country.

Monthly data on the International Finance Corporation (IFC, 2003) Stock Market Indexes $(1990=100)$ derived from Data Stream is used for emerging market stock prices. The IFC data on stock prices is the local currency denominated monthly closing values of index levels. IFC focuses on large and relatively liquid securities which foreign investors are more likely to invest in, and these indexes have certain advantages over more comprehensive local indices (Kang \& Stulz, 1997). The calculations for all markets are done in a similar fashion, which makes international comparisons possible. Furthermore, the index attempts to cover $70 \%$ of market capitalisation (Bekaert \& Harvey, 1995). In this study, real stock returns $(R)$ are defined as the first differences of log levels of real stock prices in local currency.

The data for macroeconomic variables is from the International Financial Statistics (IFS), the database of the International Monetary Fund (see Appendix A for IFS codes). Since the data for all countries are derived from the same source, we believe that cross-country and 
overtime comparisons are reliable in this relatively coherent data set. In terms of the economic fundamentals, the real money balance growth rate $(M)$ is the log difference of the money supply in national currency units deflated by the consumer price index $(\mathrm{CPI})$. The real interest rate (RI) is the change in the Central Bank discount rate adjusted for actual inflation. ${ }^{6}$ The growth of real economic activity (PROD) is represented by the log difference of the industrial production indexes, of each country which also proxy for the GDP. ${ }^{7}$ The change in real exchange rates (FX) is defined as the log difference of national currency per special drawing rights adjusted for inflation. This definition captures the value of domestic currency with respect to a basket of currencies instead of a single currency such as US dollars. ${ }^{8}$ As the global information variable, the study uses the return on S\&P500 index (S\&P), which represents the world market portfolio and controls for the degree of market liberalisation ${ }^{9}$ (Appendix B reports the descriptive statistics of these variables).

\subsection{Pre-and post-capital market liberalisation periods}

The main focus of the study is the capital market liberalisation. Choosing the date of liberalisation and distinguishing the years when capital markets are integrated from the period when they are segmented is a difficult task. We are dealing with a group of countries with very different dates of liberalisation, sequencing of reforms and adjustment patterns. Our objective here is to break up the period under study into years prior to liberalisation and years after liberalisation.

There are many complicating factors in choosing a single date of capital market liberalisation (Bekaert \& Harvey, 2000b; Bekaert, Harvey, \& Lumsdaine, 2002b). The restrictions on the flow of international capital may not be binding even before the liberalisation policies. There are alternative ways for the international investor to access the emerging capital markets such as American Depository Receipts (ADR) or country funds. Furthermore, even the implementation of the liberalisation policy, by itself, may not result in an increase in the flow of international funds. The international investor has to recognise the policy changes as credible and has to view the political and economic environment as conducive to increased profit opportunities. On the other hand, the official date of capital market liberalisation may not be meaningful if the policy change is anticipated and the agents in the economy have already started altering their behavior before the reform is announced or implemented.

The previous empirical literature on emerging market integration has tackled the issue of selecting the liberalisation dates with various methods. One group of studies chose a liberalisation date and examined the changes following that date (Kim \& Singal, 2000). The actual dates when ADR and country funds became available, as well as the announcement and implementation dates of policy changes regarding international investments, were used to date the capital market reforms. Some of these studies (Bekaert \& Harvey, 2000b; Henry, 2000a, 2000b) made use of an event study methodology to assess the stock market liberalisation. Event windows were constructed around the dates of official reforms and the effect of liberalisation were analyzed by stacking country information into these windows. Another more recent approach was the use of the endogenous break point techniques. The Bai, Lumsdaine, and Stock (1998) techniques, which search for a single break in a system of variables sharing a common break date and the Bai and Perron (1998) technique, which allows for multiple breaks in the 
single time series data were employed in deciding the impact of liberalisation on the emerging economies (Bekaert, Harvey, \& Lumsdaine, 2002a, 2002b). A third method used was to model the process of integration using regime-switching frameworks (Bekaert \& Harvey, 1995).

In all these different methodologies, one caveat remains. It has been widely recognised that capital market liberalisation is not the only policy change that occurs in these emerging markets. Trade and foreign exchange liberalisation, stabilisation policies and large-scale privatisations occur simultaneously or even precede, with a very short time interval, the changes in the regulatory framework for foreign investors. It is a difficult and sometimes impossible task to isolate the effects of these other changes from capital market liberalisation. Ignoring the concurrent occurrence of other reforms creates an upward bias in measuring the impact of the capital market liberalisation (Henry, 2000a). One must keep in mind the possibility of such a bias in interpreting results of empirical work on capital market liberalisation. However, this does not undermine the conclusions about the capital market integration. Our results provide insights into the role of capital markets in the integration process.

While examining the changes in linkages among world markets, emerging capital markets and economic fundamentals, the above mentioned methodologies would be inappropriate. Choosing a liberalisation date and either analyzing the period following it or constructing windows around that date to assess the immediate impact of liberalisation would only reveal the short-term effects of the policy change. Furthermore, the methodology is more likely to detect one time shifts in one variable at a time, such as stock returns or dividend yields. Since our objective is not to search for an unknown break in the data, it is not necessary to employ endogenous break methodology. We are interested in the changes in the interactions among a group of economic and financial variables in two alternative settings. The first is a group of emerging markets prior to capital market liberalisation and the second is the same emerging economies after their capital market reforms.

For the pre-liberalisation phase, we choose the 1976:01—1987:12 period. Table 1 reports the list of emerging markets, starting dates of our sample for each country and stock market liberalisation dates in various studies for comparison. According to the liberalisation dates of Bekaert and Harvey (2000b), 1987:12 is the last date when all countries in our sample had restricted capital markets. ${ }^{10}$ The choice for a post-liberalisation phase common to all countries is less straightforward. The starting date for capital market liberalisation is different for each country. For some countries, capital market liberalisation occurred in the late 1980s or early 1990s. In some cases, countries gradually lifted restrictions on the foreign investors. When a country moves from a segmented capital market to an integrated one, it goes through a long adjustment process, which varies considerably across countries. After careful consideration, we designated the period from 1992:01 to 1997:06 as the post-liberalisation period. According to the dates of liberalisation in Bekaert and Harvey (2000b), 11 out of 15 countries in our sample started their capital market liberalisations prior to 1992:01. To avoid any inconsistencies, for the remaining four countries, we include data only for the period following their liberalisation in our estimation sample. ${ }^{11}$

The period from 1988:01 to 1991:12, which we consider to be the transition period, is omitted from our analysis. ${ }^{12}$ Our emphasis is not on the short-term adjustments and transition dynamics that will take place following the announcement and implementation of liberalisation policies. The immediate response of economic linkages to policy changes is an interesting topic that deserves full attention with appropriate theory and methodology in a different paper. 
Table 1

Country samples and stock market liberalisation dates

\begin{tabular}{|c|c|c|c|c|c|c|}
\hline Countries & $\begin{array}{l}\text { Start of monthly } \\
\text { data (return and } \\
\text { macroeconomic } \\
\text { variables) }\end{array}$ & $\begin{array}{l}\text { Liberalisation dates } \\
\text { from Henry } \\
(2000 \mathrm{a}, 2000 \mathrm{~b})\end{array}$ & $\begin{array}{l}\text { Liberalisation dates } \\
\text { from Bekaert and } \\
\text { Harvey } \\
(2000 \mathrm{a}, 2000 \mathrm{~b})\end{array}$ & $\begin{array}{l}\text { Introduction } \\
\text { of ADR }\end{array}$ & $\begin{array}{l}\text { Introduction of } \\
\text { country funds }\end{array}$ & $\begin{array}{l}\text { Liberalisation dates } \\
\text { from Kim and } \\
\text { Segal (2000) }\end{array}$ \\
\hline Argentina-1 & 1983:11 & 1989:11 & 1989:11 & 91:08 & 91:10 & 1989:11 \\
\hline Brazil-2 & 1984:12 & 1988:03 & 1991:05 & 92:01 & $87: 10$ & 1991:05 \\
\hline Chile-3 & 1978:12 & 1987:05 & 1992:01 & 90:03 & 89:09 & 1989:10 \\
\hline Greece-5 & 1976:01 & NA & 1987:12 & 88:08 & 88:09 & 1986:08 \\
\hline India-6 & 1976:01 & 1986:06 & 1992:11 & 92:02 & 86:06 & 1992:11 \\
\hline Indonesia-7 & 1990:01 & NA & 1989:09 & 91:04 & 89:01 & 1989:09 \\
\hline Jordan-7 & 1978:02 & NA & 1995:12 & NA & NA & 1978:01 \\
\hline Korea-9 & 1976:01 & 1987:06 & 1992:01 & 90:11 & 84:08 & 1992:01 \\
\hline Malaysia-10 & 1985:01 & 1987:05 & 1988:12 & 92:08 & $87: 12$ & Prior to 1985 \\
\hline Mexico-11 & 1978:01 & 1989:05 & 1989:05 & 89:01 & $81: 06$ & 1989:05 \\
\hline Nigeria-12 & 1985:01 & NA & 1995:08 & NA & NA & Closed \\
\hline Pakistan-13 & 1985:01 & NA & 1991:02 & NA & 91:07 & 1991:02 \\
\hline Turkey-17 & 1987:01 & NA & 1989:07 & 90:07 & $89: 12$ & 1989:08 \\
\hline Venezuela-18 & 1985:01 & 1990:01 & 1990:01 & 91:08 & NA & 1990:01 \\
\hline Zimbabwe-19 & 1979:01 & NA & 1993:06 & NA & NA & 1993:06 \\
\hline
\end{tabular}


In this study, we conduct our empirical analysis using pre- and post-liberalisation periods to understand the dynamics of emerging economies following capital market liberalisation after the initial adjustments are completed. A simple comparison of the variable means for the whole sample shows that the average stock market returns, the rate of growth in money supply, production, and the percentage change in foreign exchange rates and in real interest rates declined in the post-liberalisation years. There was a decline in the variance of the return and an increase in the variance of the money supply growth and real interest changes (see Appendix C). In fact, the empirical evidence presented in Chow tests indicates that the causal flow of information among the financial and economic variables is not the same in the two periods and that the economies in our data set underwent a structural change between pre- and post-liberalisation periods (a more detailed discussion is given in Section 3.3). Hence, we focus on the comparison of the information flow analyzed by Granger orderings between variables in these two periods.

\subsection{Empirical methodology}

We apply the prototype causality model developed by Granger (1969) where the existence of causal ordering in Granger's sense implies predictability and exogeneity. The following multi-variate causality analysis is used to detect the direction of information flow among the variables. Suppose that $z_{t}=\left[R_{t}, \mathrm{RI}_{t}, M_{t}, \mathrm{PROD}_{t}, \mathrm{FX}_{t}, \mathrm{~S} \& \mathrm{P}_{t}\right]$ is a six-variate covariance stationary process with the following representation:

$$
z_{t}=A(L) z_{t-1}+e_{t}
$$

where the individual coefficients of $A(L)$ represents the coefficients of the lagged values of variable $j$ on variable $i$, and are defined as $a_{i j}(L)=\sum_{s=0}^{p} a_{i j}(s) L^{s}$ for $0<p<\infty$. $e_{t}$ is a $(k \times 1)$ vector of random shocks which are independently, identically and normally distributed with mean zero and covariance $\sum .{ }^{13}$

The causal orderings between any two variables, $z_{i}$ and $z_{j}$, can be examined by looking at whether the lag of one variable enters into the equation for another variable. Variable $\left\{z_{j}\right\}$ does not Granger cause variable $\left\{z_{i}\right\}$, if and only if all coefficients of $A(L)$ are equal to zero, which can be determined by a standard $F$-test to examine the restriction:

$$
a_{i j}(1)=a_{i j}(2)=a_{i j}(3)=\cdots=a_{i j}(p)=0
$$

Through out this paper, the "causality" terminology is used as an indicator of the direction of the information flow among various markets. For instance, if stock returns are found to be Granger causing an economic variable, then it is interpreted as the ability of the stock returns to contain information on the future course of that variable. In our analysis, we do not claim that Granger type causality should necessarily be interpreted as evidence for a structural causality from the stock returns to the economic variable in question.

\section{Empirical results}

\subsection{Diagnostic tests}

Prior to the estimations, a number of statistical tests are performed to reveal the data properties. For each individual country variable, the autocorrelation structures of the variables are 
examined. The appropriate lags are chosen by using Akaike Information Criteria (AIC) and adjusted $R^{2}$ measures. Up to 12 lags are examined for each variable. The optimum lag varies across variables and countries. Briefly, for the money supply and industrial production variables, the appropriate lags vary between 6 and 11 in different emerging countries. The tests on the stock returns of individual countries indicate that lag lengths between four and eight are required to clear the autocorrelation in this variable. For the real interest rate and exchange rate variables there is more of a discrepancy in individual country data in terms of the autoregressive structure and the optimum lag length varies between 1 and 6 for different countries for these two variables.

We chose the lag length 6 as the lag length for all the variables in estimations with pooled time series data, considering that it is the most common lag specification that leads to uncorrelated residuals in individual country data. ${ }^{14}$ Further tests on the individual country residuals obtained from the panel estimation confirmed that they are in fact white noise. More explicitly, with the selection of 6 as the appropriate lag length for all variables in pooled estimation, Breusch-Godfrey LM tests indicate that the hypothesis that the coefficients of the lagged residuals are zero cannot be rejected, hence the errors are serially uncorrelated. ${ }^{15}$ In order to test for robustness, estimations are conducted with longer lag structure, and the results on the causal orderings do not change. Hence, the results of the estimation with the six lags for all variables are reported in this paper.

Furthermore, the stationarity properties of the individual country time series data are confirmed by augmented Dickey-Fuller tests. The stationarity tests are conducted using six lags across the board in 76 regressions on all the series in each country. Results of the ADF tests and Jarque-Berra normality tests on these 72 series are reported in Appendix B, together with the descriptive statistics. Normality is rejected in most cases due to leptokurtosis, which is common in financial time series.

\subsection{Empirical estimations}

The estimations on panel data are conducted in fixed effect weighted regressions. There are alternative equation specifications, depending on the treatment of the intercept term, in estimations with cross-section time-series panel data. If the intercept terms in the set of equations are assumed to be the same for all countries, the model is known as the common intercept model. If the intercept terms are assumed to be a different value for each country, then the model is referred to as the fixed effect model. ${ }^{16}$ In empirical analysis, $F$-tests performed on alternative specifications fail to reject the null hypothesis of a common intercept in favour of the model with country specific intercept terms. However, the sample is a very rich one that includes a wide variety of emerging markets with different economic conditions. This specification imposes restrictions on the estimated coefficients. Therefore, we proceeded the estimation with a fixed effect model, whereby we include country specific intercepts. The richness of the sample in terms of country specific differences is therefore accounted for different intercepts. ${ }^{17}$ The fixed effect models are estimated using the generalised least squares estimation technique, which corrects for heteroscedasticity originating from differences in residual variance across countries. Preliminary regressions are conducted to estimate the weights that are used in the second round of estimations. 
The focus of this paper is capital market liberalization. The possible changes in the Granger type causal orderings are interpreted to be due to this structural change. We have given the details of the selection of sub-samples in Section 3.2. The formal tests to determine whether data supports the structural change between the designated pre- and post-liberalization periods are conducted by using Chow tests. We reject the null hypothesis that the coefficients are identical across both periods at the $1 \%$ significance level for all dependent variables. ${ }^{18}$ Consequently, these causal relations are investigated employing multi-variate estimations separately for preand post-liberalisation periods.

\subsection{Results of multi-variate estimations}

Our expectations were for the stock markets and domestic economies to become more integrated with the world following the liberalization process. In that context, we also anticipate linkages to be strengthened between the economic fundamentals and stock returns and between the economic variables themselves. Overall results reveal that these interactions between stock returns and domestic and global information variables are not identical during the pre- and post-liberalisation periods. Tables 2 and 3 below provide the results of multi-variate Granger causality tests and the significant parameter estimates of the coefficients of the lagged variables of the fixed effect model. ${ }^{19}$

During the pre-liberalisation period, the stock markets of emerging countries have significant interactions with world stock returns. We can reject the null hypothesis that world stock returns do not Granger cause domestic stock returns. These strong empirical links between domestic stock returns and world stock returns, even at a time when the emerging economies are not well integrated to the global financial markets, show that world returns are important determinants for emerging market returns. This Granger type causal relationship, which also continues after the capital market liberalisation, is empirical evidence that stock markets in emerging countries price the world returns as risk factors. ${ }^{20}$

Before capital market liberalisation occurs, the only economic variable that is causally prior to the domestic stock returns is the real interest rates. This variable measures the return on alternative financial assets in the economy. The negative and significant coefficient of real interest rates in Table 3 suggests that investors may be substituting equities for fixed income. However, interest rates are not linked to any other financial market or the real sector as would be expected in a well functioning economy.

During the same period, when domestic economic fundamentals are the dependent variable in the pooled regressions, an economic variable is influenced by the information content of the domestic stock returns in only one case. Stock returns Granger cause real economic activity. When we examine the individual coefficient estimates in Table 3, we see that there is a significant and positive relation between stock returns and industrial output growth. Stock returns might simply be a barometer for real economic expansion, signaling changes in real activity through their effect on expected cash flows. However, stock returns are not causally prior to any other component of the emerging economies.

In this period, there are a few significant interactions amongst the domestic economic variables detected by using the Granger type causality analysis. We observe a bi-directional flow of information between real economic activity and real money growth. Another linkage detected 
Table 2

Granger causality orderings of stock returns $(R)$ and economic fundamentals

\begin{tabular}{|c|c|c|c|c|c|c|}
\hline Dependent variables & $R$ & RI & $M$ & PROD & FX & S\&P500 \\
\hline \multicolumn{7}{|c|}{ A. Before liberalisation } \\
\hline$R$ & & $5.4032(0.000)$ & $0.8487(0.532)$ & $0.2162(0.971)$ & $0.3744(0.896)$ & $2.7489(0.012)$ \\
\hline RI & $0.2900(0.942)$ & & $0.4190(0.867)$ & $0.2891(0.942)$ & $1.0470(0.393)$ & $0.3346(0.919)$ \\
\hline$M$ & $1.7966(0.097)$ & $0.8620(0.522)$ & & $5.5192(0.000)$ & $0.4066(0.875)$ & $1.4948(0.177)$ \\
\hline PROD & $3.9511(0.001)$ & $0.7266(0.628)$ & $2.5951(0.017)$ & & $1.2497(0.278)$ & $1.8411(0.088)$ \\
\hline FX & $1.7178(0.114)$ & $1.1290(0.343)$ & $2.0076(0.062)$ & $2.8719(0.008)$ & & $1.6893(0.120)$ \\
\hline \multicolumn{7}{|l|}{ B. After liberalisation } \\
\hline$R$ & & $0.2420(0.963)$ & $3.2249(0.004)$ & $0.8549(0.528)$ & $0.9585(0.452)$ & $2.9433(0.008)$ \\
\hline RI & $32.0348(0.000)$ & & $3.2293(0.004)$ & $0.4611(0.837)$ & $1.3991(0.212)$ & $0.8652(0.520)$ \\
\hline$M$ & $1.7150(0.115)$ & $0.4687(0.832)$ & & $3.2254(0.004)$ & $2.2937(0.033)$ & $0.1370(0.991)$ \\
\hline PROD & $1.8717(0.083)$ & $0.5303(0.786)$ & $3.5967(0.002)$ & & $3.7916(0.001)$ & $2.8427(0.010)$ \\
\hline $\mathrm{FX}$ & $17.4565(0.000)$ & $2.2046(0.041)$ & $2.7698(0.011)$ & $1.1506(0.331)$ & & $4.3848(0.000)$ \\
\hline
\end{tabular}

The causality orderings between the real emerging market stock returns and economic fundamentals are examined in the following set of equations:

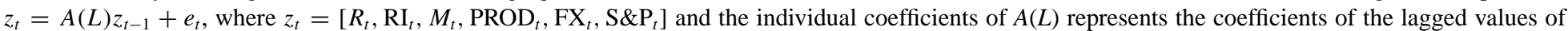
variable $j$ on variable $i$, and are defined as $a_{i j}(L)=\sum a_{i j}(s) L^{s}$ for $0<p<\infty . e_{t}$ is a $(k \times 1)$ vector of random shocks which are independently, identically and normally distributed with mean zero and covariance $\sum$. The causal orderings between any two variables, $z_{i}$ and $z_{j}$ can be examined by looking at whether the lag of one variable enters into the equation for another variable. Variable $\left\{z_{j}\right\}$ does not Granger cause variable $\left\{z_{i}\right\}$, if an only if all coefficients of $A(L)$ are equal to zero, which can be determined by a standard $F$-test to test the restriction: $a_{i j}(1)=a_{i j}(2)=a_{i j}(3)=\cdots=a_{i j}(p)=0$. The $F$-statistics and their significance are reported for the test conducted for the pre-liberalisation period (1976:01 through 1987:12) and for post-liberalisation period (1992:01 through 1997:06).The cells where the null hypothesis can be rejected at significance levels less than 5\%, shown in bold, indicate a "causal ordering." 
Table 3

Parameter estimates of Granger causality equations

\begin{tabular}{ll}
\hline Dependent variable & Parameter estimates \\
\hline A. Before liberalisation & \\
$R$ & $-0.110 \mathrm{RI}_{-1(0.000)}+0.120 \mathrm{~S} \& \mathrm{P}_{-1(0.011)}-0.150 \mathrm{~S} \& \mathrm{P}_{-3(0.102)}$ \\
$\mathrm{RI}$ & $0.058 R_{-3(0.005)}+0.057 \mathrm{PROD}_{-1(0.004)}+0.067 \mathrm{PROD}_{-2(0.002)}$ \\
$M$ & $+0.105 \mathrm{PROD}_{-3(0.000)}-0.078 \mathrm{~S} \& \mathrm{P}_{-2(0.026)}$ \\
& $0.032 R_{-2(0.045)}+0.033 R_{-3(0.041)}+0.023 R_{-5(0.052)}+0.071 M_{-3(0.004)}$ \\
PROD & $-0.012 R_{-6(0.013)}+0.013 \mathrm{RI}_{-1(0.05)}-0.036 M_{-6(0.015)}+0.035 \mathrm{PROD}_{-2(0.015)}$ \\
& $+0.040 \mathrm{PROD}_{-3(0.006)}+0.043 \mathrm{~S} \& \mathrm{P}_{-4(0.041)}$
\end{tabular}

B. After liberalisation

$R$

RI

$M$

PROD

FX

$$
\begin{aligned}
& 0.134 M_{-1(0.024)}+0.185 M_{-2(0.002)}+0.321 \mathrm{~S} \& \mathrm{P}_{-3(0.014)} \\
& +0.283{\mathrm{~S} \& \mathrm{P}_{-4(0.030)}}-0.330{\mathrm{~S} \& \mathrm{P}_{-6(0.012)}} \\
& -0.033 R_{-5(0.014)}+0.181 R_{-5(0.000)}-0.121 M_{-1(0.002)}-0.109 M_{-2(0.005)} \\
& -0.106 \mathrm{FX}_{-4(0.027)}+0.160 \mathrm{~S} \& \mathrm{P}_{-3(0.038)} \\
& 0.022 R_{-1(0.048)}+0.049 \mathrm{PROD}_{-1(0.039)}+0.071 \mathrm{PROD}_{-2(0.004)} \\
& +0.053 \mathrm{PROD}_{-1(0.029)}-0.094 \mathrm{FX}-\mathrm{P}_{-2(0.030)}-0.103 \mathrm{FX}_{-4(0.018)} \\
& -0.010 R_{-1(0.013)}+-0.067 M_{-2(0.005)}+0.069 M_{-3(0.003)}-0.130 \mathrm{FX} \\
& -2(0.000) \\
& -0.094 \mathrm{FX}_{-4(0.006)}-0.189 \mathrm{~S} \& \mathrm{P}_{-3(0.014)}+0.182 \mathrm{~S} \& \mathrm{P}_{-6(0.021)} \\
& 0.017 R_{-5(0.000)}+0.009 \mathrm{RI}_{-2(0.047)}+0.012 \mathrm{RI}_{-4(0.008)}-0.028 M_{-1(0.010)} \\
& -0.132 \mathrm{~S} \& \mathrm{P}_{-2(0.000)}-0.103 \mathrm{~S} \& \mathrm{P}_{-3(0.002)}
\end{aligned}
$$

\footnotetext{
Note. Only the coefficients with $p$-values less than 0.05 are reported. The causality orderings between the real emerging market stock returns and economic fundamentals are examined in the following set of equations: $z_{t}=$ $A(L) z_{t-1}+e_{t}$, where $z_{t}=\left[R_{t}, \mathrm{RI}_{t}, M_{t}, \mathrm{PROD}_{t}, \mathrm{FX}_{t}, \mathrm{~S} \& \mathrm{P}_{t}\right]$ and the individual coefficients of $A(L)$ represents the coefficients of the lagged values of variable $j$ on variable $i$, and are defined as $a_{i j}(L)=\sum a_{i j}(s) L^{s}$ for $0<p<\infty$. $e_{t}$ is a $(k \times 1)$ vector of random shocks which are independently, identically and normally distributed with mean zero and covariance $\sum$. The causal orderings between any two variables, $z_{i}$ and $z_{j}$ can be examined by looking at whether the lag of one variable enters into the equation for another variable. Variable $\left\{z_{j}\right\}$ does not Granger cause variable $\left\{z_{i}\right\}$, if an only if all coefficients of $A(L)$ are equal to zero, which can be determined by a standard $F$-test to test the restriction: $a_{i j}(1)=a_{i j}(2)=a_{i j}(3)=\cdots=a_{i j}(p)=0$. The $F$-statistics and their significance are reported for the test conducted for the pre-liberalisation period (1976:01 through 1987:12) and for post-liberalisation period (1992:01 through 1997:06).
}

through the causal orderings is the effect of real economic activity on real exchange rates. The significant individual coefficients reported in Table 3 indicate that real production has a positive effect on exchange rates.

Capital market liberalisation opens up the domestic economy to the world. In addition to the increased importance of world returns on the emerging economies, new links are established between economic fundamentals. The analysis of the Granger type casual relationships indicates that the interactions between the economic fundamentals and the domestic stock returns are enhanced after capital market liberalization. The empirical link between domestic and world returns that was established prior to capital market liberalization remains unchanged. This 
occurs simultaneously with an increase in the importance of the world stock returns within the domestic economy as a whole through direct influence in some sectors and indirectly in others.

During the post-liberalisation period, the stock markets of emerging countries continue to have strong empirical links with world returns, which also Granger cause real exchange rates and real economic activity. With direct information flow from world returns, both foreign exchange rates and domestic real production are now susceptible to changes in world capital markets. Despite popular belief, the most important implication of capital market liberalisation is not the integration of emerging capital markets but the emerging economies as a whole. Stock markets were open to the influence of the world before capital market liberalisation. What is new is the overall openness of the economy through real production and foreign exchange rates. Below we also discuss how these variables acquire a more integral part in the economy through their linkages with other economic fundamentals and capital markets.

During the post-liberalisation period, we can not reject the null hypothesis that the growth of real money balances does not Granger "cause" the domestic stock returns. This indicates that the growth of real money balances is empirically prior to the domestic stock returns. The growth of real balances, either as a policy tool or when accommodating to changes in the demand for real balances, upsets the relative supply of money stock with respect to the supply of other assets. Domestic investors when trying to rearrange their portfolio of assets to a new equilibrium bring about a change in all other asset prices, including stock prices. This link, which is observed in mature markets, is established in emerging markets only after capital market liberalisation.

When domestic economic fundamentals are the dependent variables in the pooled regressions, we observe that real interest rates and real exchange rates are influenced by the information content of domestic stock returns. The role of stock returns, as a leading indicator of real economic activity is no longer observed after capital market liberalization. Rather, domestic stock returns become a barometer for future real interest rate and foreign exchange rate changes. This may be an indication of the strength of the linkages between various financial markets. It is also important to note that stock markets may lead other financial markets by transferring the information that they receive from the world.

On the real side of the economy, Granger type causality analysis indicates that real economic growth responds to changes in real money balances, real exchange rates and world returns. The real side of the economy has become sensitive not only to global factors but also to local variables following capital market liberalization. Real growth is susceptible to changes in world capital markets with direct information flows as well as indirectly through the influence of foreign exchange rates, which are also Granger caused by world returns. The growth of real money balances also leads to changes in real production growth, indicating that government policy actions and related portfolio adjustments do have significant linkages to the real side of the economy. This conveys the additional information that the emerging economies as a whole are becoming more integrated.

Following liberalisation, the second important change that occurs is in the role of real exchange rates within the domestic economy. In this period, Granger type causal relationships are observed from exchange rates towards real economic activity and real money supply. The exchange rate variable is the link that connects the economy to the world through its price effect on all the goods and asset transactions. This, with the new and enhanced role of the world 
stock returns, also illustrates that the domestic economy is becoming more integrated into the changes in world economic conditions.

Third, real interest rates gain importance in integrating emerging economies following capital market liberalization. Prior to liberalisation, the interest rate variable had significant impact only in the determination of domestic stock returns, but there was no variable, global or local, causally prior to it. During the post-liberalization period, real interest rates are found to be significant factors for the changes in exchange rates. Real interest rates also respond to increases in real money balances and stock returns. In Table 3, we observe that, at the individual coefficient level, an increase in real money balances signals a decline in real interest rates. The acquired importance of the real interest rate in terms of its linkages with the real side of the economy and the foreign currency markets, as well as the stock market, is an important outcome of the capital market liberalization process. Before deregulation, the interest rates may not accurately reflect the cost of borrowing in these economies. Following liberalization, rates might behave more like market determined values approaching their equilibrium values. Moreover. financial state variables become essential in these emerging economies. They respond to information flow from one to another in a manner we are accustomed to seeing in mature economies. These linkages, which do not exist prior to liberalisation, can be attributed to the deregulation of the financial sectors, which may occur simultaneously or prior to capital market liberalisation.

\section{Conclusions}

Previous literature emphasises the world integration aspect of capital market liberalisation by increased capital inflows, related reductions in the cost of equity and enhanced growth rates. This study shows that the information content of world returns influenced emerging market returns prior to capital market liberalisation. This relationship continued after capital market liberalisation. What is new after capital market liberalisation is that emerging market economies as a whole are better integrated with the world and carry the impact of globalisation to local capital markets. Other sectors of the economy are directly influenced by the world and influence each other and capital markets both directly and indirectly through the adjustment mechanism.

Capital liberalisation opens up the domestic economy to the world. In addition to strengthening the already existing information flow from the world to the stock market, new direct links are established to the world markets through exchange rates and real economic growth. Close links are established between different segments of the economy. Interest rates, which had no significant role during the pre-liberalisation period, emerge as an important catalyst following capital market liberalisation. Interest rates are influenced by stock returns and real money balances, while influencing foreign exchange rates at the same time. Domestic stock returns become a barometer for future real interest rates and foreign exchange rate changes rather than changes in the real sector. This indicates the strength of the linkages between financial sectors. Furthermore, we observe significant information flow from real balances to domestic returns, signaling portfolio adjustments of financial assets to a new equilibrium.

However, these relationships are new to emerging economies. In mature markets, economic theory is based on the interactions between various sectors of the economy. The strength and directions of the linkages in emerging markets might change over time and across countries. At 
this stage of capital market liberalisation experience, approximately a decade later, this study can only detect their initial manifestation. We would expect these relations to become stronger over time, as these countries progress through further integration, not only globally but also domestically. We expect future work on emerging stock markets to focus more on fundamental economic relationships. This is important on two grounds. First, it has the standard implications for improved international asset pricing and portfolio allocation decisions. Risk factors and related risk premiums must be based on realistic mechanisms that are at work in emerging economies. Second, and more important, it will help policy makers in emerging markets in their management of liberalisation practices. Policy makers must gauge the progression of the liberalisation process with reference to the links that have been established as well as those that are yet to be established.

\section{Notes}

1. Please refer to Bailey and Lim (1992), Bekaert and Harvey (1995, 2000b), Henry (2000a, 2000b) for a thorough analysis.

2. Please refer to Bekaert and Harvey (1995, 1997, 2000a), Bekaert et al. (2000a), Levine et al. (2000), Kim and Singal (2000), Henry (2000a, 2000b), Levine and Zervos (1998); for a thorough analysis.

3. This study is motivated by the results of previous work by Muradoglu, Taskin, and Bigan (2000), using individual country cases.

4. Although we initially started with a sample of 19 countries, due to the lack of comparable monthly data for a complete set of macroeconomic variables, the final estimations are conducted for a smaller sample. Please refer to Table 1 for the complete list of emerging markets and sample starting dates used in the estimations.

5. Although S\&P500 is not the world index, it constitutes more than half of the world portfolio. Most fund managers investing in economies use US returns as a benchmark rather than the world portfolio.

6. We were unable to use government bond rates or long term interest rates because consistent comparable data for each country for the period considered was not accessible. For cases where the discount rate is not available, the bank rate is used.

7. In countries where no industrial production index is reported, either the manufacturing production index or the crude petroleum production index is used.

8. This is a more appropriate definition if major trade partners are countries other than the US and/or the domestic country is pursuing a foreign exchange policy that adjusts the value of domestic currency with respect to major currencies other than the US dollar.

9. See Errunza and Miller (2000) for the use of a value weighted US index representing the cost of capital in international markets in a fashion similar to measuring market segmentation.

10. In 1987:12, Greece liberalised its capital markets by allowing Europeans to invest in their domestic capital markets (Bekaert \& Harvey, 2000b). Others in the literature have used slightly different dates for the beginning of liberalisation. Henry (2000a), for example depicts the start of liberalisation as the first occurrence of any form of liberalisation, such as the establishment of a country fund or an official decree. 
11. In fact, two out of four countries (India, Jordan, Nigeria and Zimbabwe) with liberalisation dates after 1992:01 in Bekaert and Harvey (2000b) showed initial signs of capital market liberalisation before that date. India had established country funds in June of 1989, and IFC considers the liberalisation date to be December of 1988 for Jordan. In addition, return data for Indonesia is available after January of 1990 and its data is included only in the post-liberalisation estimation sample.

12. This period can be compared with the endogenous break dates in stock returns estimated in Bekaert and Harvey (2000b). According to the estimation with dividend yield information, we see that 6 out of 15 countries have breaks in stock returns within this omitted period and according to the estimation with market capitalisation information, 8 out of 15 countries return breaks within the period.

13. We assume that $E\left[e_{i t} e_{j t}\right]=0$ for all $i \neq j$.

14. In order to preserve symmetry and to be able to use OLS efficiently, it is common to use the same lag length for all equations. Moreover, as long as there are identical regressors in each equation, OLS estimates are consistent and asymptotically efficient. See Enders (1995) for details. Following the suggestions of an anonymous referee we also use the Wald test to select the lags in the VAR. Results are very similar and do not change our conclusions. Following the convention and for presentation purposes the symmetric systems are reported.

15. It is not possible to reject the hypothesis of autocorrelated errors only in few and isolated country residuals generated from the money supply and production equations.

16. A third alternative specification is the random effects model, where the intercept term is assumed to have a (unknown) fixed and a stochastic component which is independently and identically distributed with mean zero and constant variance. However, in cases where the random component and the independent variables are correlated, the coefficient estimates will be biased.

17. The results of the estimations are robust to the specification of the intercept term. The results of the common intercept model estimation are available from the authors upon request.

18. The $F$-test statistics for the Chow tests conducted on each equation are $15.42,11.44$, $4.55,2.83$ and 4.96 for $R$, RI, $M$, PROD and FX equations, respectively. The critical $F$ statistics at $1 \%$ significance level is 1.57 .

19. A detailed report of both the significant and insignificant coefficients can be found in Appendix E.

20. In order to check the robustness of our inferences, we conducted bi-variate tests as well. The results reported in Appendix D are very similar to the causal orderings reported in this section and do not change our conclusions.

\section{Acknowledgments}

We have benefited from the comments of Alec Chrystal, Clieve Granger, George VonFustenberg, Thomas Willet, Mike Bowe, Martin Walker, Ian Garrett, Stuart Hyde, Mahmut Bagheri, Warren Bailey and seminar participants at MSAF, Lancaster School of Management, Cass 
Business School, and the ITFA meeting in conjunction with the ASSA in New Orleans, FMA European Conference in Copenhagen, EFMA meeting in London, the MFS meeting in Paphos for this and earlier versions of this paper.

\section{Appendix A. Definition of variables and International Financial Statistics codes}

Exchange rates:

Money supply:

Consumer price index:

Industrial production index:

Discount rate:
End-of-month price of SDR in local currency. (IFS code 00aa)

Narrowly defined money supply (IFS code 34)

Consumer price index (IFS code 64)

Industrial production index (IFS code 66)

Discount rate (IFS code 60)

\section{Appendix B. Summary statistics of country variables}

ADF statistics (Mc. Kinnon) critical values for the smallest sample is: 3.497 (1\%), 2.891 $(5 \%), 2.582(10 \%)$. Jarque-Bera statistics critical value $\chi^{2}$ with two degrees of freedom: 6.63 $(1 \%), 5.99(5 \%), 4.61(10 \%)$. For normal distribution the skewness measure is 0 and kurtosis measure is 3

\begin{tabular}{lccccr}
\hline Argentina & R1 & RI1 & M1 & \multicolumn{1}{l}{ PROD1 } & \multicolumn{1}{l}{ FX1 } \\
\hline Mean & 0.007019 & -0.025458 & -0.000156 & 0.002970 & -0.006436 \\
Median & -0.008732 & 0.008643 & 0.001113 & 0.000000 & -0.006317 \\
Maximum & 0.888301 & 2.997486 & 0.528391 & 0.287068 & 1.296636 \\
Minimum & -0.975306 & -5.487019 & -0.396170 & -0.249041 & -0.930700 \\
SD & 0.214269 & 0.705521 & 0.121453 & 0.051911 & 0.169620 \\
Skewness & 0.402107 & -2.884592 & 0.365772 & 0.268253 & 2.433665 \\
Kurtosis & 8.071206 & 27.79878 & 5.798103 & 10.58453 & 31.61908 \\
Jarque-Bera & 179.0547 & 4402.784 & 56.80915 & 392.6460 & 5723.625 \\
Probability & 0.000000 & 0.000000 & 0.000000 & 0.000000 & 0.000000 \\
ADF(6) & -6.410221 & -9.185477 & -4.782807 & -6.899561 & -7.502257 \\
Observations & 163 & 163 & 163 & 163 & 163 \\
Brazil & $\mathrm{R} 2$ & & $\mathrm{M} 2$ & $\mathrm{PROD} 2$ & $\mathrm{FX} 2$ \\
\hline Mean & -0.084797 & -0.016461 & -0.154303 & 0.001273 & -0.003756 \\
Median & -0.003146 & 0.024102 & -0.139233 & 0.000473 & -0.002213 \\
Maximum & 6.728406 & 1.858938 & 0.637518 & 0.321939 & 0.133615 \\
Minimum & -13.55628 & -4.710996 & -1.176218 & -0.310534 & -0.285533 \\
SD & 1.375583 & 0.780288 & 0.256762 & 0.081258 & 0.052647 \\
Skewness & -6.337763 & -3.477312 & -0.192612 & -0.065095 & -2.043762 \\
Kurtosis & 70.06397 & 19.63312 & 5.111343 & 5.111657 & 13.37621 \\
Jarque-Bera & 29114.03 & 2031.422 & 28.78853 & 27.97529 & 777.3351 \\
Probability & 0.000000 & 0.000000 & 0.000001 & 0.000001 & 0.000000 \\
ADF(6) & -4.922811 & -7.341736 & -4.601566 & -9.739655 & -6.394002 \\
Observations & 150 & 150 & 150 & 150 & 150
\end{tabular}


Appendix B. (Continued)

\begin{tabular}{|c|c|c|c|c|c|}
\hline Chile & R3 & RI3 & M3 & PROD3 & FX3 \\
\hline Mean & 0.012311 & -0.009052 & 0.007936 & 0.003188 & 0.000624 \\
\hline Median & 0.009488 & -0.001927 & -0.003556 & -0.009068 & -0.003470 \\
\hline Maximum & 0.847300 & 1.285195 & 0.703223 & 0.348307 & 0.659751 \\
\hline Minimum & -0.307118 & -1.380555 & -0.182819 & -0.242562 & -0.110143 \\
\hline SD & 0.100549 & 0.339954 & 0.083770 & 0.097998 & 0.065797 \\
\hline Skewness & 2.423528 & -0.335894 & 2.991601 & 0.742879 & 7.352351 \\
\hline Kurtosis & 23.32613 & 5.955191 & 23.74954 & 4.229487 & 70.55818 \\
\hline Jarque-Bera & 4020.779 & 84.57351 & 4294.233 & 34.24682 & 44018.93 \\
\hline Probability & 0.000000 & 0.000000 & 0.000000 & 0.000000 & 0.000000 \\
\hline $\operatorname{ADF}(6)$ & -4.293750 & -7.030883 & -8.847007 & -8.124186 & -5.492945 \\
\hline Observations & 221 & 221 & 221 & 221 & 221 \\
\hline Greece & R5 & RI5 & M5 & PROD5 & FX5 \\
\hline Mean & -0.005931 & 0.001450 & 0.001771 & 0.001072 & -0.003854 \\
\hline Median & -0.014419 & 0.000189 & 0.002673 & -0.007184 & -0.007264 \\
\hline Maximum & 0.421700 & 0.240735 & 0.214591 & 0.309444 & 0.148564 \\
\hline Minimum & -0.308297 & -0.075266 & -0.169128 & -0.186509 & -0.068256 \\
\hline SD & 0.087294 & 0.026592 & 0.060899 & 0.085397 & 0.024331 \\
\hline Skewness & 1.143687 & 5.811298 & 0.099988 & 1.120146 & 1.976124 \\
\hline Kurtosis & 7.428925 & 52.41169 & 3.642437 & 4.716093 & 13.02711 \\
\hline Jarque-Bera & 265.0396 & 27483.73 & 4.828972 & 84.94804 & 1239.074 \\
\hline Probability & 0.000000 & 0.000000 & 0.089413 & 0.000000 & 0.000000 \\
\hline $\mathrm{ADF}(6)$ & -5.252218 & -5.330241 & -8.300737 & -8.671725 & -5.997959 \\
\hline Observations & 256 & 256 & 256 & 256 & 256 \\
\hline India & R6 & RI6 & M6 & PROD6 & FX6 \\
\hline Mean & 0.006048 & 0.000398 & 0.004545 & 0.004853 & -0.000880 \\
\hline Median & 0.002957 & 0.000000 & 0.006487 & 0.006736 & -0.003042 \\
\hline Maximum & 0.377143 & 0.104902 & 0.097163 & 0.214870 & 0.186593 \\
\hline Minimum & -0.291199 & -0.096681 & -0.249380 & -0.328798 & -0.050278 \\
\hline SD & 0.078243 & 0.013292 & 0.032338 & 0.072934 & 0.024780 \\
\hline Skewness & 0.499344 & 1.806328 & -1.809461 & -1.086248 & 3.418444 \\
\hline Kurtosis & 5.539123 & 51.35776 & 16.96834 & 6.452978 & 26.51840 \\
\hline Jarque-Bera & 79.40826 & 25082.92 & 2220.918 & 177.5232 & 6398.488 \\
\hline Probability & 0.000000 & 0.000000 & 0.000000 & 0.000000 & 0.000000 \\
\hline $\operatorname{ADF}(6)$ & -5.308392 & -3.406512 & -8.162146 & -9.106704 & -6.895081 \\
\hline Observations & 256 & 256 & 256 & 256 & 256 \\
\hline Indonesia & R7 & RI7 & M7 & PROD7 & FX7 \\
\hline Mean & -0.000505 & -0.000578 & 0.006692 & 0.000763 & -0.002732 \\
\hline Median & -0.003914 & -0.004778 & 0.007610 & 0.000000 & -0.001563 \\
\hline Maximum & 0.181007 & 0.091775 & 0.141051 & 0.135761 & 0.040718 \\
\hline Minimum & -0.238182 & -0.052461 & -0.108233 & -0.142701 & -0.052796 \\
\hline SD & 0.085247 & 0.027758 & 0.040985 & 0.060093 & 0.016732 \\
\hline Skewness & -0.149964 & 0.572105 & 0.476790 & 0.038778 & -0.490948 \\
\hline Kurtosis & 3.131000 & 3.369502 & 4.750979 & 2.717330 & 4.193284 \\
\hline
\end{tabular}


Appendix B. (Continued)

\begin{tabular}{|c|c|c|c|c|c|}
\hline Indonesia & R7 & RI7 & M7 & PROD7 & FX7 \\
\hline Jarque-Bera & 0.397231 & 5.361313 & 14.74153 & 0.318609 & 8.855665 \\
\hline Probability & 0.819865 & 0.068518 & 0.000629 & 0.852737 & 0.011940 \\
\hline $\mathrm{ADF}(6)$ & -4.349487 & -5.736073 & -5.989657 & -7.934570 & -5.684943 \\
\hline Observations & 89 & 89 & 89 & 89 & 89 \\
\hline Jordan & R8 & RI8 & M8 & PROD8 & FX8 \\
\hline Mean & 0.002956 & 0.002361 & 0.002106 & 0.007036 & -0.001474 \\
\hline Median & -0.006203 & $5.49 \mathrm{E}-05$ & 0.004252 & 0.017060 & -0.002291 \\
\hline Maximum & 0.248530 & 0.245818 & 0.068584 & 0.263338 & 0.414950 \\
\hline Minimum & -0.159006 & -0.039626 & -0.073895 & -0.231236 & -0.072201 \\
\hline $\mathrm{SD}$ & 0.049482 & 0.021063 & 0.027739 & 0.091337 & 0.036595 \\
\hline Skewness & 1.013512 & 9.128505 & -0.145794 & -0.060864 & 7.932193 \\
\hline Kurtosis & 6.590928 & 100.4336 & 2.837432 & 3.027647 & 92.14571 \\
\hline Jarque-Bera & 130.3609 & 75337.45 & 0.854469 & 0.119464 & 62856.21 \\
\hline Probability & 0.000000 & 0.000000 & 0.652311 & 0.942017 & 0.000000 \\
\hline $\mathrm{ADF}(6)$ & -5.846693 & -4.575556 & -8.117947 & -7.011139 & -5.294725 \\
\hline Observations & 184 & 184 & 184 & 184 & 184 \\
\hline Korea & R9 & RI9 & M9 & PROD9 & FX9 \\
\hline Mean & -0.001466 & -0.004020 & 0.006589 & 0.008690 & -0.003588 \\
\hline Median & -0.011051 & $4.89 \mathrm{E}-06$ & 0.005409 & 0.008690 & -0.004114 \\
\hline Maximum & 0.357054 & 0.336689 & 0.242989 & 0.188163 & 0.146343 \\
\hline Minimum & -0.227354 & -0.788879 & -0.162448 & -0.124488 & -0.070028 \\
\hline $\mathrm{SD}$ & 0.083475 & 0.077648 & 0.061928 & 0.031680 & 0.021609 \\
\hline Skewness & 0.543120 & -3.772187 & 0.228142 & 0.510524 & 1.038705 \\
\hline Kurtosis & 4.299073 & 48.88775 & 3.612425 & 10.25942 & 11.81225 \\
\hline Jarque-Bera & 30.58677 & 23067.77 & 6.221431 & 573.2443 & 874.3623 \\
\hline Probability & 0.000000 & 0.000000 & 0.044569 & 0.000000 & 0.000000 \\
\hline $\mathrm{ADF}(6)$ & -5.928472 & -5.651547 & -8.320007 & -6.168979 & -5.452296 \\
\hline Observations & 256 & 256 & 256 & 256 & 256 \\
\hline Malaysia & R10 & RI10 & M10 & PROD10 & FX10 \\
\hline Mean & 0.005619 & 0.002515 & 0.009588 & 0.007926 & $-4.75 E-06$ \\
\hline Median & 0.010055 & 0.000262 & 0.008677 & 0.003088 & 0.000422 \\
\hline Maximum & 0.232749 & 0.190637 & 0.164426 & 0.209430 & 0.040967 \\
\hline Minimum & -0.376986 & -0.413081 & -0.077994 & -0.156552 & -0.055883 \\
\hline SD & 0.076884 & 0.071635 & 0.036233 & 0.067839 & 0.018330 \\
\hline Skewness & -0.871153 & -1.688327 & 0.706629 & 0.077134 & -0.353427 \\
\hline Kurtosis & 6.619159 & 13.00909 & 5.839593 & 3.099039 & 3.537120 \\
\hline Jarque-Bera & 100.1649 & 692.7480 & 62.45947 & 0.208646 & 4.893037 \\
\hline Probability & 0.000000 & 0.000000 & 0.000000 & 0.900934 & 0.086595 \\
\hline $\mathrm{ADF}(6)$ & -5.469599 & -5.765288 & -7.851303 & -8.754591 & -5.604552 \\
\hline Observations & 149 & 149 & 149 & 149 & 149 \\
\hline Mexico & R11 & RI11 & M11 & PROD11 & FX11 \\
\hline Mean & 0.009742 & 0.001260 & $-1.00 \mathrm{E}-05$ & 0.001799 & -0.002719 \\
\hline
\end{tabular}


Appendix B. (Continued)

\begin{tabular}{|c|c|c|c|c|c|}
\hline Mexico & R11 & RI11 & M11 & PROD11 & FX11 \\
\hline Median & 0.017594 & 0.000106 & -0.000600 & -0.003275 & -0.005871 \\
\hline Maximum & 0.306996 & 0.516283 & 0.352497 & 0.109267 & 0.567695 \\
\hline Minimum & -0.672710 & -0.472394 & -0.190729 & -0.105770 & -0.233019 \\
\hline SD & 0.126533 & 0.091936 & 0.067857 & 0.038111 & 0.068147 \\
\hline Skewness & -1.557198 & -0.584006 & 0.507754 & 0.170014 & 4.435356 \\
\hline Kurtosis & 9.350452 & 13.01858 & 7.120887 & 3.075261 & 37.32753 \\
\hline Jarque-Bera & 383.5457 & 779.9783 & 138.0994 & 0.929835 & 9637.530 \\
\hline Probability & 0.000000 & 0.000000 & 0.000000 & 0.628187 & 0.000000 \\
\hline $\operatorname{ADF}(6)$ & -5.320273 & -4.526150 & -5.890762 & -6.481129 & -7.279083 \\
\hline Observations & 184 & 184 & 184 & 184 & 184 \\
\hline Nigeria & $\mathrm{R} 12$ & RI12 & M12 & PROD12 & FX12 \\
\hline Mean & 0.014727 & 0.003900 & -0.021260 & 0.004002 & 0.007438 \\
\hline Median & 0.013079 & $9.17 \mathrm{E}-05$ & -0.002039 & 0.007081 & -0.001531 \\
\hline Maximum & 0.193889 & 0.333760 & 0.181602 & 0.277999 & 0.874289 \\
\hline Minimum & -0.227770 & -0.176009 & -2.314130 & -0.353791 & -0.226937 \\
\hline $\mathrm{SD}$ & 0.052347 & 0.049800 & 0.227165 & 0.092063 & 0.102364 \\
\hline Skewness & 0.092025 & 4.002206 & -9.174335 & -0.512531 & 5.349806 \\
\hline Kurtosis & 8.413103 & 32.89591 & 92.70314 & 6.030359 & 46.60330 \\
\hline Jarque-Bera & 138.1216 & 4509.811 & 39471.50 & 48.18427 & 9490.728 \\
\hline Probability & 0.000000 & 0.000000 & 0.000000 & 0.000000 & 0.000000 \\
\hline $\operatorname{ADF}(6)$ & -3.840700 & -5.757982 & -3.136237 & -7.810120 & -4.556328 \\
\hline Observations & 113 & 113 & 113 & 113 & 113 \\
\hline Pakistan & $\mathrm{R} 13$ & RI13 & M13 & PROD13 & FX13 \\
\hline Mean & 0.006964 & 0.005021 & 0.004877 & 0.004442 & 0.002072 \\
\hline Median & 0.002210 & $-3.29 \mathrm{E}-05$ & 0.004140 & 0.006123 & 0.000146 \\
\hline Maximum & 0.298632 & 0.529835 & 0.069911 & 0.252702 & 0.074683 \\
\hline Minimum & -0.180131 & -0.125503 & -0.121298 & -0.232361 & -0.059760 \\
\hline SD & 0.068045 & 0.050855 & 0.024647 & 0.103659 & 0.021083 \\
\hline Skewness & 0.976030 & 8.757241 & -0.736713 & -0.062677 & 0.334524 \\
\hline Kurtosis & 7.235117 & 90.39814 & 7.187140 & 2.656674 & 4.531776 \\
\hline Jarque-Bera & 115.9827 & 42374.36 & 105.0833 & 0.712461 & 14.90114 \\
\hline Probability & 0.000000 & 0.000000 & 0.000000 & 0.700311 & 0.000581 \\
\hline $\operatorname{AFD}(6)$ & -3.828807 & -6.314061 & -7.773879 & -11.24967 & -5.381420 \\
\hline Observations & 128 & 128 & 128 & 128 & 128 \\
\hline Turkey & $\mathrm{R} 17$ & RI17 & M17 & PROD17 & FX17 \\
\hline Mean & 0.007171 & 0.006341 & -0.001571 & 0.004539 & -0.002613 \\
\hline Median & -0.018067 & -0.000149 & -0.006073 & -0.003513 & -0.013822 \\
\hline Maximum & 0.538605 & 0.469074 & 0.209807 & 0.207123 & 0.660550 \\
\hline Minimum & -0.381943 & -0.428462 & -0.306721 & -0.218205 & -0.543737 \\
\hline SD & 0.179177 & 0.083805 & 0.094848 & 0.087556 & 0.101936 \\
\hline Skewness & 0.499485 & 1.503203 & -0.407393 & -0.078556 & 1.887731 \\
\hline Kurtosis & 3.149497 & 19.27594 & 3.874535 & 2.575942 & 24.40449 \\
\hline
\end{tabular}


Appendix B. (Continued)

\begin{tabular}{lccccc}
\hline Turkey & R17 & RI17 & M17 & PROD17 & FX17 \\
\hline Jarque-Bera & 5.271500 & 1415.381 & 7.381547 & 1.056634 & 2440.766 \\
Probability & 0.071665 & 0.000000 & 0.024953 & 0.589597 & 0.000000 \\
ADF(6) & -4.182721 & -5.481244 & -6.675814 & -6.024131 & -5.163338 \\
Observations & 124 & 124 & 124 & 124 & 124 \\
Venezuela & R18 & RI18 & M18 & PROD18 & FX18 \\
\hline Mean & 0.008410 & 0.001503 & -0.006166 & 0.004926 & 0.000257 \\
Median & 0.012013 & $2.82 \mathrm{E}-05$ & -0.006868 & 0.006643 & -0.012821 \\
Maximum & 0.360926 & 0.665790 & 0.145270 & 0.186748 & 0.719171 \\
Minimum & -0.433680 & -0.379926 & -0.255000 & -0.236523 & -0.221493 \\
SD & 0.114529 & 0.127059 & 0.069238 & 0.059667 & 0.106444 \\
Skewness & -0.310819 & 0.319687 & -0.560103 & -0.210594 & 4.648942 \\
Kurtosis & 4.901436 & 8.738009 & 4.611761 & 4.295303 & 28.48146 \\
Jarque-Bera & 24.67833 & 205.5569 & 23.75790 & 11.44045 & 4537.159 \\
Probability & 0.000004 & 0.000000 & 0.000007 & 0.003279 & 0.000000 \\
ADF(6) & -3.112131 & -3.711599 & -5.001404 & -6.669624 & -5.276169 \\
Observations & 148 & 148 & 148 & 148 & 148 \\
Zimbabwe & $\mathrm{R} 19$ & $\mathrm{RI} 19$ & $\mathrm{M} 19$ & PROD19 & FX19 \\
\hline Mean & 0.009552 & 0.007372 & 0.004252 & 0.003866 & 0.000611 \\
Median & 0.016939 & $9.37 \mathrm{E}-05$ & 0.008871 & 0.013176 & -0.004588 \\
Maximum & 0.407686 & 0.405292 & 0.171447 & 0.332209 & 0.195189 \\
Minimum & -0.334879 & -0.137968 & -0.161745 & -0.262687 & -0.174434 \\
SD & 0.097930 & 0.046289 & 0.059314 & 0.088759 & 0.044694 \\
Skewness & -0.319440 & 5.544843 & -0.116306 & -0.398774 & 1.031061 \\
Kurtosis & 5.309288 & 42.00380 & 3.534881 & 5.265396 & 9.845335 \\
Jarque-Bera & 44.73178 & 12811.66 & 2.650772 & 44.94312 & 398.2396 \\
Probability & 0.000000 & 0.000000 & 0.265700 & 0.000000 & 0.000000 \\
ADF(6) & -4.236659 & -2.211130 & -8.468700 & -7.601486 & -6.367596 \\
Observations & 187 & 187 & 187 & 187 & 187 \\
& & & & & \\
& & & & & \\
\end{tabular}

S\&P500

\begin{tabular}{lr}
\hline Mean & 0.004592 \\
Median & 0.006691 \\
Maximum & 0.128799 \\
Minimum & -0.247705 \\
SD & 0.040307 \\
Skewness & -0.943595 \\
Kurtosis & 8.619398 \\
Jarque-Bera & 376.2814 \\
Probability & 0.000000 \\
ADF(6) & -5.703522 \\
Observations & 257 \\
\hline
\end{tabular}




\section{Appendix C}

Mean of the variables for pre- and post-liberalisation periods

\begin{tabular}{|c|c|c|c|c|c|c|c|c|c|c|}
\hline \multirow{2}{*}{$\begin{array}{l}\text { Countries/ } \\
\text { variable }\end{array}$} & \multicolumn{2}{|l|}{ Return } & \multicolumn{2}{|l|}{ Interest rates } & \multicolumn{2}{|c|}{ Money supply } & \multicolumn{2}{|c|}{ Production } & \multicolumn{2}{|c|}{ Foreign exchange } \\
\hline & Pre & Post & Pre & Post & Pre & Post & Pre & Post & Pre & Post \\
\hline Argentina-1 & -0.0087 & 0.0041 & -0.0111 & -0.0171 & 0.0094 & 0.0095 & -0.0022 & 0.0053 & -0.0032 & -0.0048 \\
\hline Brazil-2 & 0.1742 & -0.2960 & 0.013391 & -0.0737 & -0.0845 & -0.1676 & 0.0008 & 0.0058 & 0.0053 & -0.0086 \\
\hline Chile-3 & 0.0104 & 0.0057 & -0.0084 & -0.0099 & 0.0090 & 0.0062 & 0.0021 & 0.0034 & 0.0076 & -0.0062 \\
\hline Greece-5 & -0.0119 & 0.0014 & 0.0053 & -0.0041 & $-6.5 \mathrm{E}-05$ & 0.0037 & 0.0018 & 0.0010 & -0.0042 & -0.0016 \\
\hline India-6 & 0.0048 & -0.0006 & 0.0008 & -0.00 & 0.0031 & 0.0055 & 0.0053 & 0.0047 & -0.0027 & -0.0024 \\
\hline Indonesia-7 & NA & 0.0098 & 0.0030 & -0.00 & 0.0075 & 0.0065 & -0.0005 & $-3.12 \mathrm{E}-05$ & 0.0023 & -0.0036 \\
\hline Jordan- 8 & 0.0052 & -0.0003 & 0.0011 & 0.00 & 0.00 & -0.0065 & 0.0096 & 0.0106 & -0.0044 & -0.0064 \\
\hline Korea-9 & -0.0010 & -0.0048 & -0.0051 & -0.0051 & 0.0071 & 0.0036 & 0.0101 & 0.0064 & -0.0027 & -0.0022 \\
\hline Malaysia-10 & -0.0045 & 0.0078 & -0.0130 & -0.0007 & 0.0050 & 0.0129 & 0.0066 & 0.0078 & 0.0099 & -0.0048 \\
\hline Mexico-11 & 0.0074 & -0.0003 & 0.0181 & -0.0133 & -0.0118 & -0.0042 & 0.0005 & 0.0026 & 0.0039 & -0.0012 \\
\hline Nigeria-12 & 0.0088 & 0.0372 & & $9.50 \mathrm{E}-05$ & & -0.0841 & & & 0.0507 & -0.0233 \\
\hline Pakistan-13 & 0.0056 & -0.0012 & $4.41 \mathrm{E}-05$ & 0.0143 & 0.0090 & 0.0023 & 0.0062 & 0.0032 & 0.0103 & -0.0019 \\
\hline Turkey-17 & 0.1174 & 0.0064 & -0.0002 & 0.0015 & 0.0250 & -0.0013 & 0.0223 & 0.0033 & 0.0018 & 0.0012 \\
\hline Venezuella-18 & 0.0380 & -0.0116 & -0.0103 & -0.0097 & -0.0077 & -0.0030 & 0.0040 & 0.0038 & 0.0151 & -0.0068 \\
\hline Zimbabwe-19 & -0.0015 & 0.0313 & 0.0066 & -0.0027 & 0.0005 & 0.0118 & 0.0043 & $-5.34 \mathrm{E}-05$ & -0.0010 & -0.0038 \\
\hline Average & 0.0195 & 0.0072 & 0.0005 & -0.0017 & 0.0037 & -0.0076 & 0.0071 & 0.0046 & 0.0093 & -0.0055 \\
\hline
\end{tabular}

Variance of the variables for pre- and post-liberalisation periods

\begin{tabular}{|c|c|c|c|c|c|c|c|c|c|c|}
\hline \multirow{2}{*}{$\begin{array}{l}\text { Countries/ } \\
\text { variable }\end{array}$} & \multicolumn{2}{|l|}{ Return } & \multicolumn{2}{|c|}{ Interest rates } & \multicolumn{2}{|c|}{ Money supply } & \multicolumn{2}{|c|}{ Production } & \multicolumn{2}{|c|}{ Foreign exchange } \\
\hline & Pre & Post & Pre & Post & Pre & Post & Pre & Post & Pre & Post \\
\hline Argentina-1 & 0.2521 & 0.1001 & 0.4460 & 0.1212 & 0.1500 & 0.0514 & 0.0467 & 0.0630 & 0.0412 & 0.0178 \\
\hline Brazil-2 & 1.1251 & 1.8873 & 0.7509 & 0.6042 & 0.2386 & 0.2494 & 0.0667 & 0.0663 & 0.0313 & 0.0428 \\
\hline Chile-3 & 0.1267 & 0.0631 & 0.2640 & 0.3891 & 0.0899 & 0.0783 & 0.1066 & 0.0818 & 0.0910 & 0.0238 \\
\hline Greece-5 & 0.0753 & 0.0704 & 0.0308 & 0.0250 & 0.0631 & 0.0603 & 0.0870 & 0.0867 & 0.0286 & 0.0178 \\
\hline India-6 & 0.0567 & 0.1054 & 0.0091 & 0.0159 & 0.0364 & 0.0260 & 0.0663 & 0.0744 & 0.0179 & 0.0307 \\
\hline Indonesia-7 & NA & 0.0723 & 0.1037 & 0.0232 & 0.0294 & 0.0319 & 0.0747 & 0.0573 & 0.0509 & 0.0167 \\
\hline Jordan-8 & 0.0512 & 0.0334 & 0.0122 & 0.0021 & 0.0285 & 0.0206 & 0.0882 & 0.1073 & 0.0189 & 0.0196 \\
\hline Korea-9 & 0.0911 & 0.0702 & 0.1014 & 0.0416 & 0.0575 & 0.0585 & 0.0248 & 0.0429 & 0.0234 & 0.0154 \\
\hline Malaysia-10 & 0.1013 & 0.0694 & 0.0811 & 0.0790 & 0.0344 & 0.0408 & 0.0846 & 0.0504 & 0.0155 & 0.0189 \\
\hline Mexico-11 & 0.1689 & 0.0810 & 0.0569 & 0.1034 & 0.0662 & 0.0488 & 0.0349 & 0.0422 & 0.0830 & 0.0695 \\
\hline Nigeria-12 & 0.0402 & 0.0584 & 0.0620 & 0.0017 & 0.070 & 0.4247 & 0.1437 & 0.0541 & 0.1558 & 0.0262 \\
\hline Pakistan-13 & 0.0328 & 0.0948 & 0.0011 & 0.0856 & 0.0197 & 0.0305 & 0.0937 & 0.1094 & 0.0183 & 0.0241 \\
\hline Turkey-17 & 0.2437 & 0.1559 & 0.0007 & 0.0909 & 0.0744 & 0.1000 & 0.0705 & 0.0839 & 0.0516 & 0.1367 \\
\hline Venezuella-18 & 0.0570 & 0.1101 & 0.0333 & 0.1426 & 0.0467 & 0.0693 & 0.0758 & 0.0586 & 0.1161 & 0.0969 \\
\hline Zimbabwe-19 & 0.1074 & 0.0869 & 0.0482 & 0.0271 & 0.0522 & 0.0753 & 0.0843 & 0.0953 & 0.0325 & 0.0619 \\
\hline Average & 0.0993 & 0.0844 & 0.0441 & 0.0638 & 0.0500 & 0.0965 & 0.0778 & 0.0716 & 0.0572 & 0.0521 \\
\hline
\end{tabular}


Appendix D. Bi-variate Granger causality orderings of stock returns $(\boldsymbol{R})$ and economic fundamentals

\begin{tabular}{|c|c|c|c|c|c|c|}
\hline Dependent variables & $R$ & RI & $M$ & PROD & FX & S\&P500 \\
\hline \multicolumn{7}{|c|}{ A. Before liberalisation } \\
\hline$R$ & & $2.4211(0.025)$ & $1.2999(0.254)$ & $0.1404(0.991)$ & $0.1647(0.986)$ & $2.8773(0.009)$ \\
\hline RI & $0.4318(0.858)$ & & $1.3476(0.233)$ & $0.2671(0.952)$ & $1.5836(0.148)$ & $0.8475(0.533)$ \\
\hline$M$ & $2.8850(0.009)$ & $0.9551(0.455)$ & & $6.3901(0.000)$ & $0.6798(0.666)$ & $0.5570(0.765)$ \\
\hline PROD & $4.7182(0.000)$ & $0.7712(0.593)$ & $4.0984(0.000)$ & & $1.5599(0.155)$ & $1.5769(0.150)$ \\
\hline $\mathrm{FX}$ & $2.1111(0.049)$ & $0.0860(0.998)$ & $4.1175(0.000)$ & $1.7278(0.111)$ & & $3.0647(0.006)$ \\
\hline \multicolumn{7}{|l|}{ B. After liberalisation } \\
\hline$R$ & & $0.6317(0.705)$ & $4.6444(0.000)$ & $1.1906(0.309)$ & $1.9910(0.065)$ & $3.1886(0.004)$ \\
\hline RI & $20.5656(0.000)$ & & $1.1568(0.328)$ & $0.2451(0.961)$ & $1.0211(0.410)$ & $0.8700(0.517)$ \\
\hline$M$ & $1.2164(0.256)$ & $0.4145(0.870)$ & & $3.2289(0.004)$ & $2.6623(0.015)$ & $0.4298(0.859)$ \\
\hline PROD & $2.6622(0.015)$ & $0.7946(0.574)$ & $3.2925(0.003)$ & & $2.9947(0.007)$ & $2.3695(0.028)$ \\
\hline $\mathrm{FX}$ & $14.5745(0.000)$ & $1.5592(0.156)$ & $2.3858(0.027)$ & $1.6001(0.144)$ & & $3.7388(0.001)$ \\
\hline
\end{tabular}

The bi-variate causality orderings between the real emerging market stock returns and economic fundamentals are examined in the following set of equations: $z_{t}=A(L) z_{t-1}+e_{t}$, where $z_{t}=\left[z_{i}, z_{j}\right]$ and a subset of $z_{t}=\left[R_{t}, \mathrm{RI}_{t}, M_{t}, \mathrm{PROD}_{t}, \mathrm{FX}_{t}, \mathrm{~S} \& \mathrm{P}_{t}\right]$ and the individual coefficients of $A(L)$ represents the coefficients of the lagged values of variable $j$ on variable $i$, and are defined as $a_{i j}(L)=\sum a_{i j}(s) L^{s}$ for $0<p<\infty . e_{t}$ is a $(k \times 1)$ vector of random shocks which are independently, identically and normally distributed with mean zero and covariance $\sum$. The causal orderings between any two variables, $z_{i}$ and $z_{j}$ can be examined by looking at whether the lag of one variable enters into the equation for another variable. Variable $\left\{z_{j}\right\}$ does not Granger cause variable $\left\{z_{i}\right\}$, if an only if all coefficients of $A(L)$ are equal to zero, which can be determined by a standard $F$-test to test the restriction: $a_{i j}(1)=a_{i j}(2)=a_{i j}(3)=\cdots=a_{i j}(p)=0$. The $F$-statistics and their significance are reported for the test conducted for the pre-liberalisation period (1976:01 through 1987:12) and for post-liberalisation period (1992:01 through 1997:06). The cells where the null hypothesis can be rejected at significance levels less than 5\%, shown in bold, indicate a "causal ordering." 
Appendix E. Granger causality orderings of stock returns $(\boldsymbol{R})$ and economic fundamentals

\begin{tabular}{|c|c|c|c|c|c|c|c|c|c|c|c|c|}
\hline \multirow{2}{*}{$\begin{array}{l}\begin{array}{l}\text { Dependent } \\
\text { variables }\end{array} \\
R\end{array}$} & \multicolumn{12}{|c|}{ A. Before liberalization } \\
\hline & $R_{-1}$ & $R_{-2}$ & $R_{-3}$ & $R_{-4}$ & $R_{-5}$ & $R_{-6}$ & $\mathrm{RI}_{-1}$ & $\mathrm{RI}_{-2}$ & $\mathrm{RI}_{-3}$ & $\mathrm{RI}_{-4}$ & $\mathrm{RI}_{-5}$ & $\mathrm{RI}_{-6}$ \\
\hline & $0.066(0.05)$ & $0.016(0.63)$ & $0.070(0.04)$ & $0.034(0.04)$ & $0.032(0.05)$ & $0.009(0.61)$ & $-0.110(0.00)$ & $-0.042(0.06)$ & $-0.009(0.68)$ & $-0.011(0.62)$ & $0.028(0.21)$ & $0.004(0.87)$ \\
\hline & $M_{-1}$ & $M_{-2}$ & $M_{-3}$ & $M_{-4}$ & $M_{-5}$ & $M_{-6}$ & $\mathrm{PROD}_{-1}$ & $\mathrm{PROD}_{-2}$ & $\mathrm{PROD}_{-3}$ & $\mathrm{PROD}_{-4}$ & $\mathrm{PROD}_{-5}$ & $\mathrm{PROD}_{-6}$ \\
\hline & $0.069(0.14)$ & $-0.025(0.61)$ & $0.013(0.80)$ & $-0.035(0.47)$ & $0.002(0.95)$ & $-0.053(0.26)$ & $0.007(0.82)$ & $0.020(0.54)$ & $0.018(0.58)$ & $0.015(0.65)$ & $0.012(0.71)$ & $-0.016(0.58)$ \\
\hline & $\mathrm{FX}_{-1}$ & $\mathrm{FX}_{-2}$ & $\mathrm{FX}_{-3}$ & $\mathrm{FX}_{-4}$ & $\mathrm{FX}_{-5}$ & $\mathrm{FX}_{-6}$ & $S \& P_{-1}$ & $S \& P_{-2}$ & ${\mathrm{~S} \& \mathrm{P}_{-3}}$ & ${\mathrm{~S} \& \mathrm{P}_{-4}}_{4}$ & $\mathrm{~S} \& \mathrm{P}_{-5}$ & $\mathrm{~S} \& \mathrm{P}_{-6}$ \\
\hline & $-0.011(0.81)$ & $0.054(0.21)$ & $-0.001(0.98)$ & $0.038(0.39)$ & $-0.016(0.71)$ & $0.018(0.67)$ & $0.120(0.01)$ & $-0.097(0.09)$ & $-0.150(0.01)$ & $0.034(0.56)$ & $-0.032(0.58)$ & $-0.028(0.64)$ \\
\hline \multirow[t]{6}{*}{ RI } & $R_{-1}$ & $R_{-2}$ & $R_{-3}$ & $R_{-4}$ & $R_{-5}$ & $R_{-6}$ & $\mathrm{RI}_{-1}$ & $\mathrm{RI}_{-2}$ & $\mathrm{RI}_{-3}$ & $\mathrm{RI}_{-4}$ & $\mathrm{RI}_{-5}$ & RI_6 \\
\hline & $-0.011(0.53)$ & $0.005(0.77)$ & $-0.003(0.87)$ & $0.001(0.95)$ & $-0.013(0.47)$ & $-0.015(0.42)$ & $0.089(0.01)$ & $-0.119(0.00)$ & $0.035(0.30)$ & $-0.085(0.01)$ & $-0.020(0.54)$ & $0.087(0.01)$ \\
\hline & $M_{-1}$ & $M_{-2}$ & $M_{-3}$ & $M_{-4}$ & $M_{-5}$ & $M_{-6}$ & $\mathrm{PROD}_{-1}$ & $\mathrm{PROD}_{-2}$ & $\mathrm{PROD}_{-3}$ & $\mathrm{PROD}_{-4}$ & $\mathrm{PROD}_{-5}$ & $\mathrm{PROD}_{-6}$ \\
\hline & $-0.037(0.21)$ & $-0.002(0.94)$ & $0.013(0.66)$ & $0.012(0.67)$ & $0.001(0.98)$ & $0.016(0.58)$ & $-0.003(0.81)$ & $-0.009(0.58)$ & $0.014(0.44)$ & $0.013(0.49)$ & $0.003(0.88)$ & $-0.04(0.82)$ \\
\hline & $\mathrm{FX}_{-1}$ & $\mathrm{FX}_{-2}$ & $\mathrm{FX}_{-3}$ & $\mathrm{FX}_{-4}$ & $\mathrm{FX}_{-5}$ & $\mathrm{FX}_{-6}$ & ${\mathrm{~S} \& \mathrm{P}_{-1}}_{1}$ & ${\mathrm{~S} \& \mathrm{P}_{-2}}$ & ${\mathrm{~S} \& \mathrm{P}_{-3}}$ & ${\mathrm{~S} \& \mathrm{P}_{-4}}$ & ${\mathrm{~S} \& \mathrm{P}_{-5}}$ & $S \& P_{-6}$ \\
\hline & $-0.064(0.06)$ & $-0.046(0.18)$ & $0.011(0.75)$ & $-0.007(0.83)$ & $-0.005(0.88)$ & $-0.036(0.28)$ & $-0.002(0.94)$ & $-0.025(0.40)$ & $-0.016(0.60)$ & $-0.023(0.45)$ & $0.010(0.72)$ & $0.018(0.53)$ \\
\hline \multirow[t]{5}{*}{ M } & $R_{-1}$ & $R_{-2}$ & $R_{-3}$ & $R_{-4}$ & $R_{-5}$ & $R_{-6}$ & $\mathrm{RI}_{-1}$ & $\mathrm{RI}_{-2}$ & $\mathrm{RI}_{-3}$ & $\mathrm{RI}_{-4}$ & $\mathrm{RI}_{-5}$ & $\mathrm{RI}_{-6}$ \\
\hline & $-0.011(0.56)$ & $0.015(0.47)$ & $0.058(0.01)$ & $0.010(0.55)$ & $0.005(0.80)$ & $0.014(0.41)$ & $-0.034(0.05)$ & $-0.006(0.76)$ & $-0.022(0.23)$ & $-0.014(0.46)$ & $-0.003(0.86)$ & $-0.006(0.75)$ \\
\hline & $M_{-1}$ & $M_{-2}$ & $M_{-3}$ & $M_{-4}$ & $M_{-5}$ & $M_{-6}$ & PROD $_{-1}$ & PROD $_{-2}$ & PROD $_{-3}$ & $\mathrm{PROD}_{-4}$ & $\mathrm{PROD}_{-5}$ & PROD $_{-6}$ \\
\hline & $\mathrm{FX}_{-1}$ & $\mathrm{FX}_{-2}$ & $\mathrm{FX}_{-3}$ & $\mathrm{FX}_{-4}$ & $\mathrm{FX}_{-5}$ & $\mathrm{FX}_{-6}$ & ${\mathrm{~S} \& \mathrm{P}_{-1}}$ & ${\mathrm{~S} \& \mathrm{P}_{-2}}$ & ${\mathrm{~S} \& \mathrm{P}_{-3}}$ & ${\mathrm{~S} \& \mathrm{P}_{-4}}$ & ${\mathrm{~S} \& \mathrm{P}_{-5}}$ & ${\mathrm{~S} \& \mathrm{P}_{-6}}$ \\
\hline & $0.012(0.74)$ & $0.006(0.87)$ & $-0.056(0.14)$ & $0.003(0.95)$ & $-0.001(0.98)$ & $-0.004(0.92)$ & $-0.037(0.21)$ & $-0.078(0.03)$ & $-0.010(0.78)$ & $-0.013(0.72)$ & $0.046(0.20)$ & $-0.013(0.74)$ \\
\hline \multirow[t]{6}{*}{ PROD } & $R_{-1}$ & $R_{-2}$ & $R_{-3}$ & $R_{-4}$ & $R_{-5}$ & $R_{-6}$ & $\mathrm{RI}_{-1}$ & $\mathrm{RI}_{-2}$ & $\mathrm{RI}_{-3}$ & $\mathrm{RI}_{-4}$ & $\mathrm{RI}_{-5}$ & $\mathrm{RI}_{-6}$ \\
\hline & $0.029(0.06)$ & $0.032(0.05)$ & $0.033(0.04)$ & $0.007(0.37)$ & $0.023(0.01)$ & $0.010(0.21)$ & $-0.007(0.48)$ & $-0.002(0.84)$ & $0.011(0.32)$ & $-0.005(0.62)$ & $0.017(0.10)$ & $-0.005(0.61)$ \\
\hline & $M_{-1}$ & $M_{-2}$ & $M_{-3}$ & $M_{-4}$ & $M_{-5}$ & $M_{-6}$ & $\mathrm{PROD}_{-1}$ & $\mathrm{PROD}_{-2}$ & $\mathrm{PROD}_{-3}$ & $\mathrm{PROD}_{-4}$ & $\mathrm{PROD}_{-5}$ & $\mathrm{PROD}_{-6}$ \\
\hline & $-0.027(0.27)$ & $-0.018(0.49)$ & $0.071(0.00)$ & $0.008(0.75)$ & $0.029(0.24)$ & $-0.033(0.16)$ & $-0.493(0.00)$ & $-0.313(0.00)$ & $-0.188(0.00)$ & $-0.209(0.00)$ & $-0.086(0.02)$ & $-0.121(0.00)$ \\
\hline & $\mathrm{FX}_{-1}$ & $\mathrm{FX}_{-2}$ & $\mathrm{FX}_{-3}$ & $\mathrm{FX}_{-4}$ & $\mathrm{FX}_{-5}$ & $\mathrm{FX}_{-6}$ & ${\mathrm{~S} \& \mathrm{P}_{-1}}$ & ${\mathrm{~S} \& \mathrm{P}_{-2}}$ & ${\mathrm{~S} \& \mathrm{P}_{-3}}$ & ${\mathrm{~S} \& \mathrm{P}_{-4}}$ & ${\mathrm{~S} \& \mathrm{P}_{-5}}$ & ${\mathrm{~S} \& \mathrm{P}_{-6}}$ \\
\hline & $-0.026(0.46)$ & $-0.059(0.10)$ & $-0.011(0.76)$ & $-0.015(0.67)$ & $-0.062(0.08)$ & $-0.045(0.19)$ & $0.036(0.30)$ & $-0.044(0.29)$ & $0.079(0.06)$ & $0.078(0.06)$ & $0.015(0.72)$ & $0.046(0.29)$ \\
\hline \multirow[t]{6}{*}{ FX } & $R_{-1}$ & $R_{-2}$ & $R_{-3}$ & $R_{-4}$ & $R_{-5}$ & $R_{-6}$ & $\mathrm{RI}_{-1}$ & $\mathrm{RI}_{-2}$ & $\mathrm{RI}_{-3}$ & $\mathrm{RI}_{-4}$ & $\mathrm{RI}_{-5}$ & $\mathrm{RI}_{-6}$ \\
\hline & $0.006(0.51)$ & $0.013(0.22)$ & $0.004(0.72)$ & $0.005(0.32)$ & $-0.006(0.24)$ & $-0.012(0.01)$ & $0.013(0.05)$ & $0.011(0.13)$ & $0.001(0.88)$ & $0.004(0.61)$ & $0.004(0.58)$ & $0.004(0.56)$ \\
\hline & $M_{-1}$ & $M_{-2}$ & $M_{-3}$ & $M_{-4}$ & $M_{-5}$ & $M_{-6}$ & $\mathrm{PROD}_{-1}$ & $\mathrm{PROD}_{-2}$ & $\mathrm{PROD}_{-3}$ & $\mathrm{PROD}_{-4}$ & $\mathrm{PROD}_{-5}$ & $\mathrm{PROD}_{-6}$ \\
\hline & $0.016(0.34)$ & $0.030(0.07)$ & $-0.008(0.61)$ & $-0.004(0.79)$ & $-0.019(0.24)$ & $-0.036(0.02)$ & $0.024(0.06)$ & $0.035(0.02)$ & $0.040(0.01)$ & $0.006(0.69)$ & $0.014(0.35)$ & $-0.019(0.14)$ \\
\hline & $\mathrm{FX}_{-1}$ & $\mathrm{FX}_{-2}$ & $\mathrm{FX}_{-3}$ & $\mathrm{FX}_{-4}$ & $\mathrm{FX}_{-5}$ & $\mathrm{FX}_{-6}$ & ${\mathrm{~S} \& \mathrm{P}_{-1}}_{1}$ & $\mathrm{~S} \& \mathrm{P}_{-2}$ & ${\mathrm{~S} \& \mathrm{P}_{-3}}$ & ${\mathrm{~S} \& \mathrm{P}_{-4}}$ & $S \& P_{-5}$ & ${\mathrm{~S} \& \mathrm{P}_{-6}}$ \\
\hline & $-0.055(0.09)$ & $0.013(0.69)$ & $0.026(0.43)$ & $-0.052(0.12)$ & $0.016(0.63)$ & $-0.019(0.53)$ & $-0.012(0.51)$ & $0.008(0.71)$ & $0.040(0.05)$ & $0.043(0.04)$ & $-0.014(0.49)$ & $-0.021(0.32)$ \\
\hline
\end{tabular}




\begin{tabular}{|c|c|c|c|c|c|c|c|c|c|c|c|c|}
\hline \multirow[t]{5}{*}{$R$} & $R_{-1}$ & $R_{-2}$ & $R_{-3}$ & $R_{-4}$ & $R_{-5}$ & $R_{-6}$ & $\mathrm{RI}_{-1}$ & $\mathrm{RI}_{-2}$ & $\mathrm{RI}_{-3}$ & $\mathrm{RI}_{-4}$ & $\mathrm{RI}_{-5}$ & $\mathrm{RI}_{-6}$ \\
\hline & $\begin{array}{l}0.026(0.47) \\
M_{-1}\end{array}$ & $\begin{array}{l}0.037(0.30) \\
M_{-2}\end{array}$ & $\begin{array}{l}-0.071(0.05) \\
M_{-3}\end{array}$ & $\begin{array}{l}-0.004(0.91) \\
M_{-4}\end{array}$ & $\begin{array}{l}-0.006(0.86) \\
M_{-5}\end{array}$ & $\begin{array}{l}-0.014(0.69) \\
M_{-6}\end{array}$ & $\begin{array}{l}-0.014(0.59) \\
\text { PROD }_{-1}\end{array}$ & $\begin{array}{l}-0.015(0.57) \\
\text { PROD }_{-2}\end{array}$ & $\begin{array}{l}0.012(0.64) \\
\text { PROD }_{-3}\end{array}$ & $\begin{array}{l}-0.012(0.64) \\
\text { PROD_4 }\end{array}$ & $\begin{array}{l}0.008(0.75) \\
\text { PROD }_{-5}\end{array}$ & $\begin{array}{l}0.007(0.77) \\
\text { PROD }_{-6}\end{array}$ \\
\hline & $0.134(0.03)$ & $0.185(0.00)$ & $-0.054(0.35)$ & $-0.110(0.05)$ & $0.054(0.34)$ & $0.015(0.79)$ & $-0.089(0.07)$ & $-0.051(0.33)$ & $0.033(0.54)$ & $0.004(0.95)$ & $-0.029(0.59)$ & $0.011(0.83)$ \\
\hline & $\mathrm{FX}_{-1}$ & $\mathrm{FX}_{-2}$ & $\mathrm{FX}_{-3}$ & $\mathrm{FX}_{-4}$ & $\mathrm{FX}_{-5}$ & $\mathrm{FX}_{-6}$ & $S \& P_{-1}$ & ${\mathrm{~S} \& \mathrm{P}_{-2}}$ & ${\mathrm{~S} \& \mathrm{P}_{-3}}$ & ${\mathrm{~S} \& \mathrm{P}_{-4}}$ & ${\mathrm{~S} \& \mathrm{P}_{-5}}$ & ${\mathrm{~S} \& \mathrm{P}_{-6}}$ \\
\hline & $-0.066(0.34)$ & $-0.118(0.09)$ & $-0.061(0.39)$ & $-0.003(0.96)$ & $0.025(0.73)$ & $0.084(0.23)$ & $0.163(0.18)$ & $-0.037(0.77)$ & $0.321(0.01)$ & $0.283(0.03)$ & $-0.183(0.17)$ & $-0.330(0.01)$ \\
\hline \multirow[t]{5}{*}{ RI } & $R_{-1}$ & $R_{-2}$ & $R_{-3}$ & $R_{-4}$ & $R_{-5}$ & $R_{-6}$ & $\mathrm{RI}_{-1}$ & $\mathrm{RI}_{-2}$ & $\mathrm{RI}_{-3}$ & $\mathrm{RI}_{-4}$ & $\mathrm{RI}_{-5}$ & $\mathrm{RI}_{-6}$ \\
\hline & $\begin{array}{l}-0033(0.01) \\
\end{array}$ & $-0.005(0.731)$ & $0.001(0.95)$ & $-0.013(0.32)$ & $0.181(0.00)$ & $0.007(0.64)$ & $0.119(0.00)$ & $-0.017(0.61)$ & $-0.049(0.14)$ & $-0.058(0.08)$ & $0.070(0.03)$ & $-0.023(0.47)$ \\
\hline & $-0.121(0.00)$ & $-0.109(0.01)$ & $-0.062(0.10)$ & $-0.021(0.56)$ & $-0.021(0.55)$ & $0.036(0.31)$ & $0.021(0.43)$ & $0.023(0.40)$ & $0.015(0.59)$ & $0.041(0.15)$ & $0.009(0.75)$ & $0.000(0.99)$ \\
\hline & $\mathrm{FX}_{-1}$ & $\mathrm{FX}_{-2}$ & $\mathrm{FX}_{-3}$ & $\mathrm{FX}_{-4}$ & $\mathrm{FX}_{-5}$ & $\mathrm{FX}_{-6}$ & ${\mathrm{~S} \& \mathrm{P}_{-1}}_{1}$ & ${\mathrm{~S} \& \mathrm{P}_{-2}}_{2}$ & $\mathrm{~S} \& \mathrm{P}_{-3}$ & ${\mathrm{~S} \& \mathrm{P}_{-4}}$ & $\mathrm{~S} \& \mathrm{P}_{-5}$ & ${\mathrm{~S} \& \mathrm{P}_{-6}}$ \\
\hline & $0.025(0.60)$ & $-0.002(0.97)$ & $-0.009(0.85)$ & $-0.106(0.03)$ & $0.073(0.13)$ & $-0.032(0.49)$ & $-0.035(0.63)$ & $0.015(0.84)$ & $0.160(0.04)$ & $0.044(0.57)$ & $-0.088(0.27)$ & $-0.033(0.68)$ \\
\hline \multirow[t]{5}{*}{$M$} & $R_{-1}$ & $R_{-2}$ & $R_{-3}$ & $R_{-4}$ & $R_{-5}$ & $R_{-6}$ & $\mathrm{RI}_{-1}$ & $\mathrm{RI}_{-2}$ & $\mathrm{RI}_{-3}$ & $\mathrm{RI}_{-4}$ & $\mathrm{RI}_{-5}$ & $\mathrm{RI}_{-6}$ \\
\hline & $0.022(0.05)$ & $0.001(0.37)$ & $0.012(0.29)$ & $0.011(0.30)$ & $0.020(0.07)$ & $0.011(0.32)$ & $-0.017(0.35)$ & $0.015(0.38)$ & $-0.002(0.90)$ & $0.019(0.27)$ & $-0.003(0.87)$ & $0.008(0.64)$ \\
\hline & $M_{-1}$ & $M_{-2}$ & $M_{-3}$ & $M_{-4}$ & $M_{-5}$ & $M_{-6}$ & $\mathrm{PROD}_{-1}$ & $\mathrm{PROD}_{-2}$ & $\mathrm{PROD}_{-3}$ & $\mathrm{PROD}_{-4}$ & $\mathrm{PROD}_{-5}$ & $\mathrm{PROD}_{-6}$ \\
\hline & $\begin{array}{c}-0.111(0.00) \\
\end{array}$ & $0.032(0.37)$ & $-0.051(0.14)$ & $-0.006(0.87)$ & $-0.047(0.18)$ & $-0.032(0.36)$ & $0.049(0.04)$ & $0.071(0.00)$ & $0.053(0.03)$ & $-0.028(0.27)$ & $-0.016(0.55)$ & $-0.017(0.50)$ \\
\hline & $0.007(0.88)$ & $-0.094(0.03)$ & $0.017(0.69)$ & $-0.103(0.02)$ & $-0.075(0.08)$ & $0.025(0.55)$ & $-0.034(0.61)$ & $-0.033(0.63)$ & $0.024(0.74)$ & $-0.022(0.75)$ & $-0.024(0.74)$ & $0.001(0.99)$ \\
\hline \multirow[t]{6}{*}{ PROD } & $R_{-1}$ & $R_{-2}$ & $R_{-3}$ & $R_{-4}$ & $R_{-5}$ & $R_{-6}$ & $\mathrm{RI}_{-1}$ & $\mathrm{RI}_{-2}$ & $\mathrm{RI}_{-3}$ & $\mathrm{RI}_{-4}$ & $\mathrm{RI}_{-5}$ & $\mathrm{RI}_{-6}$ \\
\hline & $-0.010(0.01)$ & $0.003(0.37)$ & $-0.006(0.16)$ & $-0.003(0.44)$ & $-0.006(0.15)$ & $-0.004(0.42)$ & $-0.009(0.50)$ & $-0.001(0.91)$ & $-0.011(0.26)$ & $-0.002(0.82)$ & $-0.006(0.56)$ & $0.011(0.25)$ \\
\hline & $M_{-1}$ & $M_{-2}$ & $M_{-3}$ & $M_{-4}$ & $M_{-5}$ & $M_{-6}$ & $\mathrm{PROD}_{-1}$ & $\mathrm{PROD}_{-2}$ & $\mathrm{PROD}_{-3}$ & $\mathrm{PROD}_{-4}$ & $\mathrm{PROD}_{-5}$ & $\mathrm{PROD}_{-6}$ \\
\hline & $0.011(0.66)$ & $-0.067(0.01)$ & $0.069(0.00)$ & $0.036(0.12)$ & $0.021(0.36)$ & $-0.007(0.77)$ & $-0.470(0.00)$ & $-0.237(0.00)$ & $-0.165(0.00)$ & $-0.243(0.00)$ & $-0.143(0.00)$ & $-0.161(0.00)$ \\
\hline & $\mathrm{FX}_{-1}$ & $\mathrm{FX}_{-2}$ & $\mathrm{FX}_{-3}$ & $\mathrm{FX}_{-4}$ & $\mathrm{FX}_{-5}$ & $\mathrm{FX}_{-6}$ & ${\mathrm{~S} \& \mathrm{P}_{-1}}_{1}$ & ${\mathrm{~S} \& \mathrm{P}_{-2}}_{2}$ & $\mathrm{~S} \& \mathrm{P}_{-3}$ & ${\mathrm{~S} \& \mathrm{P}_{-4}}_{4}$ & ${\mathrm{~S} \& \mathrm{P}_{-5}}$ & ${\mathrm{~S} \& \mathrm{P}_{-6}}$ \\
\hline & $-0.025(0.46)$ & $-0.130(0.00)$ & $0.020(0.55)$ & $-0.094(0.01)$ & $0.021(0.53)$ & $-0.047(0.16)$ & $0.028(0.69)$ & $-0.002(0.98)$ & $-0.189(0.01)$ & $0.076(0.33)$ & $0.001(0.99)$ & $0.182(0.02)$ \\
\hline \multirow[t]{6}{*}{$\mathrm{FX}$} & $R_{-1}$ & $R_{-2}$ & $R_{-3}$ & $R_{-4}$ & $R_{-5}$ & $R_{-6}$ & $\mathrm{RI}_{-1}$ & $\mathrm{RI}_{-2}$ & $\mathrm{RI}_{-3}$ & $\mathrm{RI}_{-4}$ & $\mathrm{RI}_{-5}$ & RI_6 \\
\hline & $-0.001(0.44)$ & $-0.001(0.46)$ & $-0.001(0.61)$ & $-0.002(0.32)$ & $0.017(0.00)$ & $0.006(0.01)$ & $0.002(0.69)$ & $0.009(0.05)$ & $0.002(0.72)$ & $0.012(0.01)$ & $0.005(0.24)$ & $0.008(0.08)$ \\
\hline & $M_{-1}$ & $M_{-2}$ & $M_{-3}$ & $M_{-4}$ & $M_{-5}$ & $M_{-6}$ & $\mathrm{PROD}_{-1}$ & $\mathrm{PROD}_{-2}$ & $\mathrm{PROD}_{-3}$ & $\mathrm{PROD}_{-4}$ & $\mathrm{PROD}_{-5}$ & $\mathrm{PROD}_{-6}$ \\
\hline & $-0.028(0.01)$ & $-0.020(0.07)$ & $0.008(0.47)$ & $-0.016(0.14)$ & $-0.010(0.38)$ & $0.014(0.22)$ & $-0.024(0.06)$ & $-0.003(0.81)$ & $-0.023(0.10)$ & $-0.013(0.36)$ & $-0.016(0.27)$ & $-0.012(0.39)$ \\
\hline & $\mathrm{FX}_{-1}$ & $\mathrm{FX}_{-2}$ & $\mathrm{FX}_{-3}$ & $\mathrm{FX}_{-4}$ & $\mathrm{FX}_{-5}$ & $\mathrm{FX}_{-6}$ & ${\mathrm{~S} \& \mathrm{P}_{-1}}_{1}$ & ${\mathrm{~S} \& \mathrm{P}_{-2}}$ & ${\mathrm{~S} \& \mathrm{P}_{-3}}_{3}$ & ${\mathrm{~S} \& \mathrm{P}_{-4}}$ & $\mathrm{~S} \& \mathrm{P}_{-5}$ & ${\mathrm{~S} \& \mathrm{P}_{-6}}$ \\
\hline & $-0.038(0.28)$ & $-0.156(0.00)$ & $-0.052(0.13)$ & $-0.140(0.00)$ & $-0.089(0.01)$ & $-0.096(0.00)$ & $-0.064(0.05)$ & $-0.132(0.00)$ & $-0.103(0.00)$ & $0.016(0.64)$ & $0.035(0.32)$ & $-0.030(0.39)$ \\
\hline
\end{tabular}

The causality orderings between the real emerging market stock returns and economic fundamentals are examined in the following set of equations: $z_{t}=A(L) z_{t-1}+e_{t}$, where $z_{t}=\left[R_{t}, \mathrm{RI}_{t}, M_{t}, \mathrm{PROD}_{t}, \mathrm{FX}_{t}, \mathrm{~S} \& \mathrm{P} t\right]$ and the individual coefficients of $A(L)$ represents the coefficients of the lagged values of variable $j$ on variable $i$, and are defined as $a_{i j}(L)=\sum a_{i j}(s) L^{s}$ for $0<p<\infty . e_{t}$ is a $(k \times 1)$ vector of random shocks which are independently, identically and normally distributed with mean zero and covariance $\sum$. The causal orderings between any two variables, $z_{i}$ and $z_{j}$ can be examined by looking at whether the lag of one variable enters into the equation for another variable. Variable $\left\{z_{j}\right\}$ does not Granger cause variable $\left\{z_{i}\right\}$, if an only if all coefficients of $A(L)$ are equal to zero, which can be determined by a standard $F$-test to test the restriction: $a_{i j}(1)=a_{i j}(2)=a_{i j}(3)=\cdots=a_{i j}(p)=0$. The estimated coefficient values and the $p$ values are reported for the pre-liberalisation period (1976:01 through 1987:12) and for post-liberalisation period (1992:01 through 1997:06). 


\section{References}

Bacchetta, P., \& Wincoop, E. V. (2000). Capital flows to emerging markets: Liberalisation, overshooting and volatility. In: S. Edwards (Ed.), Capital inflows to emerging markets. University of Chicago Press.

Bai, J., Lumsdaine, R., \& Stock, J. H. (1998). Testing for and dating breaks in stationary and nonstationary multivariate time series. Review of Economic Studies, 65, 395-432.

Bai, J., \& Perron, P. (1998). Estimating and testing linear models with multiple structural changes. Review of Economics Studies, 65(3), 395-432.

Bailey, W., \& Lim, J. (1992, Spring). Evaluating the diversification benchmark of the new country funds. Journal of Portfolio Management, 74-89.

Bekaert, G., \& Harvey, C. (1995). Time varying world market integration. Journal of Finance, 50, 403-444.

Bekaert, G., \& Harvey, C. (1997). Emerging equity market volatility. Journal of Financial Economics, 43, $28-78$.

Bekaert, G., \& Harvey, C. (2000a). Capital flows and the behavior of emerging markets equity returns. In: Edwards, S. (Ed.), Capital inflows to emerging markets (pp. 159-194). University of Chicago Press.

Bekaert, G., \& Harvey, C. (2000b). Foreign speculators and emerging equity markets. Journal of Finance, 55, 565-613.

Bekaert, G., Harvey, C., \& Lumsdaine, R. L. (2000a). Dynamics of emerging market equity flows. Journal of International Money and Finance, 21(3), 295-350.

Bekaert, G., Harvey, C., \& Lumsdaine, R. L. (2000b). Dating the integration of world equity markets. Journal of International Money and Finance, 65(2), 203-249.

Enders, W., 1995. Applied econometric time series. New York: Wiley.

Errunza, V., \& Miller, D. (2000). Market segmentation and the cost of capital in international equity markets. Journal of Finance and Quantitative Analysis, 35(4), 577-600.

Granger, C. W. J. (1969). Investigating causal relations by econometric models and cross-spectral methods. Econometrica, 55, 251-276.

Hartman, M. A., \& Khambata, D. (1993). Emerging stock markets investment and strategies of the future. The Colombia Journal of World Business, 28, 83-104.

Henry, P. B. (2000a). Stock market liberalisation, economic reform, and emerging equity prices. The Journal of Finance, 55, 529-564.

Henry, P. B. (2000b). Do stock market liberalisations cause investment booms? Journal of Financial Economics, 58, 301-334.

Emerging Markets Data Base, International Finance Corporation (IFC). International Financial Statistics, International Monetary Fund, Washington, DC, 1980-2000.

Kang, J., \& Stulz, R. (1997). Why is there a home-bias? An analysis of foreign portfolio equity ownership in Japan. Journal of Financial Economics, 46, 1-28.

Kim, E. H., \& Singal, V. (2000). The fear of globalizing capital markets. Emerging Markets Review, 1(3), 183-198.

Levine, R., Loayza, N., \& Beck, T. (2000). Financial intermediation and growth: causality and causes. Journal of Monetary Economics, 46, 31-77.

Levine, R., \& Zervos, S. (1998). Stock markets, banks and economic growth. American Economic Review, 88, 942-963.

Mc. Kinnon, R. I. (1973). Money and capital in economic development. Washington, DC: The Brookings Institution.

Muradoglu, G., Taskin, F., \& Bigan, I. (2000). Causality between stock returns and macroeconomic variables in emerging markets. Russian and East European Finance and Trade, 36(6), 22-37.

Murinde, V. (1996). Development banking and finance. Avebury, Aldershot.

Show, E. S. (1973). Financial deepening in economic development. New York: Oxford University Press.

Stulz, R. M. (1999). International portfolio flows and security markets. In: Fieldstein, M. (Ed.), International capital flows (pp.257-293). University Chicago Press. 